\title{
An estimation of CPI biases in Argentina 1985-2005 and its implications on real income growth and income distribution
}

\author{
Pablo Gluzmann ${ }^{1,2}$ (D) Federico Sturzenegger ${ }^{3,4}$
}

Received: 9 August 2017/Revised: 15 September 2017/ Accepted: 1 October 2017

(C) The Author(s) 2017. This article is an open access publication

\begin{abstract}
We use the shifts in Engel curves calculated from household surveys to estimate CPI biases in Argentina between 1985 and 2005. We find that real earning levels increased during this period between 4.3 and $5.7 \%$ faster per year than previously estimated. More surprisingly, relative to conventional wisdom, that income distribution has improved throughout this period.
\end{abstract}

Keywords Argentina - GDP growth · Engel Curve · CPI Bias

JEL Classification $\mathrm{N} 1 \cdot \mathrm{O} 47$

This paper was prepared for the Argentine Exceptionalism Conference at Harvard Kennedy School on February 13th, 2009. We would like to give special thanks to conference participants, Javier Alejo, Guillermo Cruces, Leonardo Gasparini, Agustin Lodola, Ana Pacheco and Guido Porto for their useful comments.

$\triangle$ Pablo Gluzmann

pgluzman@cedlas.org

Federico Sturzenegger

fsturzen@utdt.edu

1 Centro de Estudios Distributivos Laborales y Sociales, CEDLAS, Departamento de Economía de la Universidad Nacional de La Plata, FCE-UNLP, Buenos Aires, Argentina

2 Consejo Nacional de Investigaciones Científicas y Técnicas, CONICET, Buenos Aires, Argentina

3 Universidad Torcuato Di-Tella, UTDT, Buenos Aires, Argentina

4 Banco Central de la República Argentina, BCRA, Buenos Aires, Argentina 


\section{Introduction}

Argentina has always been considered a basket case. No better proof of this fact than the name of this collection which refers to Argentina's exceptionalism, thus assuming that there is something unusual, "exceptional", for good or bad, regarding Argentina's economic performance.

It is a well-known fact that at the turn of the XXth century, Argentina was among the richest countries in the world ${ }^{1}$ and that after WWII started a long period of economic decline. ${ }^{2}$ While by the turn of the XXIst century, Argentina still was, in PPP terms, the richest among large Latin American countries, and it had lost significant ground relative to its peer group of a century ago. This long stagnation has become to some an apparently unavoidable fate, only to be interrupted occasionally by brief growth spurts that inevitably provided the stage for the following crisis (a process that has been dubbed "stop go" dynamics). ${ }^{3}$ In fact, studies about the Argentine perception of the business cycle indicate that Argentines tend to become pessimists in the midst of each economic boom as if anticipating the unavoidable next crisis (see Gabrielli and Rouillet 2003).

This stagnation and perennial process of going forward and backwards has permeated not only the economic sphere, but has also been relevant in politics, as Argentina witnessed a string of military interventions between 1930 and 1983. It is perhaps in this parallel dimension, where Argentines feel that real progress has been made since 1983, as nowadays, there is virtually no possibility of an interruption of the democratic political process. However, has this improvement in the political sphere been matched by a similar success in economic performance? Not in the collective imagination. Since the return of democracy, the country has experienced two hyperinflations, several defaults and restructurings of its debt, many large devaluations, periods of persistent high inflation, deflation, introduction of parallel currencies, and deep economic crises. This poor economic performance has implied a volatile evolution of its per capita GDP growth and a deteriorating income distribution, as shown in Fig. 1. It is the long period between the $70 \mathrm{~s}$ and the first decade of the 21st century that has built the belief of a stagnant economy. Taking 1983, the year of the restoration of democracy, as a starting point, output per capita has grown only $1.5 \%$ when considering the period until 2009. However, the per capita income of 1983, with ups and downs, was left behind only in 2002-2003. The per capita income of 1980 was left behind only in 2005 , i.e., 25 years later.

\footnotetext{
${ }^{1}$ Gerchunoff and Llach (2003a, 2003b and 2004) have studied in detail this phenomenon, as well as other papers in this special collection (Llach; Glaeser and Campante; and Alvaredo, Cruces and Gasparini). Many of these authors found that Argentina was less developed in terms of education, health, inequality and other determinants of growth than countries with similar levels of product.

2 Most part of this special collection analyzes the determinants of this poor performance. Brambilla, Galiani and Porto and Galiani and Somaini relate it to trade policy, Di Tella to political beliefs and Taylor to insufficient domestic savings and investment.

3 See for example Diaz Alejandro (1970) and Gerchunoff (2004).
} 


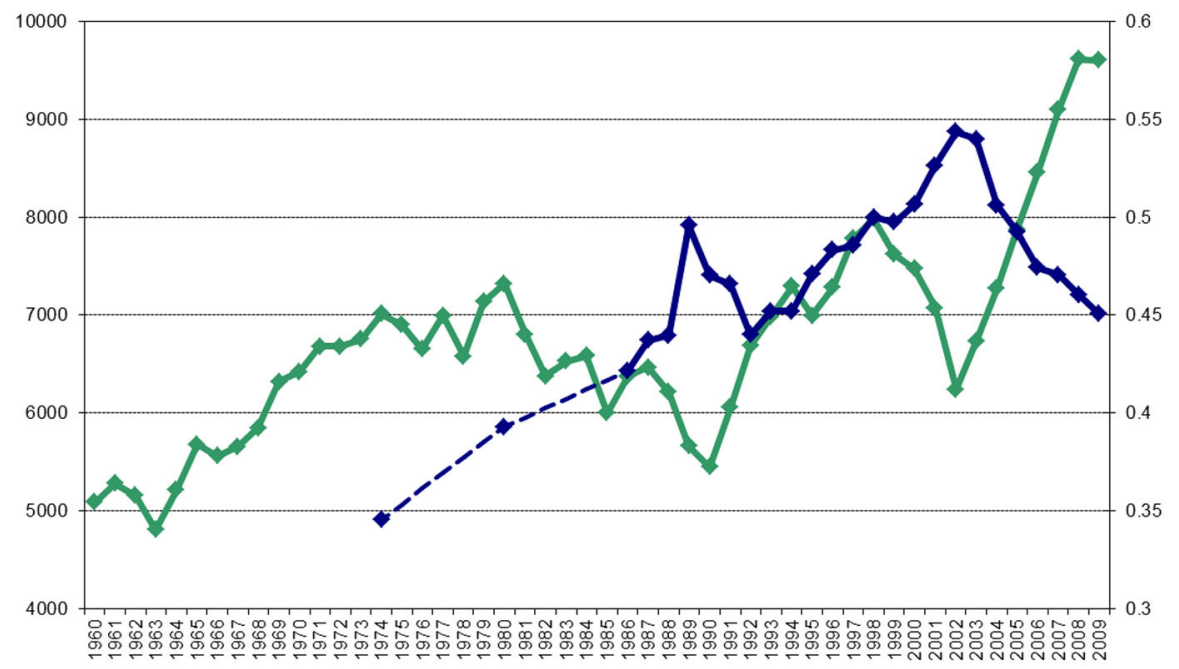

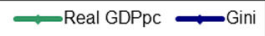

Fig. 1 Real GDP growth and income distribution. Source the Gini coefficient includes only Buenos Aires and its metropolitan area; it was computed using the Socioeconomic Database of Latin America and the Caribbean (CEDLAS-WB); the Real GDPpc are values reported in World Development Indicators (WB)

All the historical literature accepts this perspective as given, ${ }^{4}$ providing a cohesive and unanimous answer to the question about economic performance: Argentina's exceptional bad performance since democracy is considered a stylized fact.

The purpose of this paper is to challenge this view. In fact, we want to challenge the view that economic performance during Argentina's recent democracy has been dismal, both in terms of earnings growth as well as in terms of income distribution. Using the shift in the Engel curves to re-estimate the relevant price levels, we will argue that real earning growth has been steady and much bigger than measured and that income distribution has improved. If we are able to convince our readers of our results, our work would throw a completely new light on recent economic performance. Under this new light, the exceptionalism that has been the focus of the other papers in this special collection would appear to have been left behind already two decades ago. With commodity prices on a relatively strong footing, a region that appears to be increasingly in order, and large wealth increases from the development of mining, agricultural, and energy resources, the prospect for Argentina looks bright in the foreseeable future.

\footnotetext{
4 There are many articles that analyze the performance of Argentina during this period. See for example Damill and Frenkel (1992 and 2003), Damill et al. (2002), Gerchunoff and Llach (2003a) for output performance and its determinants. For papers specially focused on income distribution and its determinants see Altimir and Beccaria (2001), Altimir et al. (2002), Gasparini (2005), Lindenboim et al. (2005) and Cruces and Gasparini (2009).
} 
The outline of this paper is extremely simple. The next section explains the methodology to correct the bias in the price levels typically used to estimate real income growth; section results shows the estimation results; and the last section provides some final thoughts. Our conclusions are that Argentina's exceptionalism is a presumption that still needs to be proven and that Argentina's economic performance during our recent democracy, both in terms of income distribution and earnings growth, has been substantially better than accepted in the economic debate.

\section{Methodology}

It is standard to use income as the most relevant measure to estimate well-being. However, to obtain a comparable measure of income over time, it is necessary to deflate the nominal measures at each specific moment by a price series, most commonly the consumer price index (CPI). In the case of Argentina, in particular, the one used is that corresponding to the city of Buenos Aires and its metropolitan area. This a Laspeyres type index, with a fixed basket, and subject to a series of well-known biases. 5

First, these indexes overestimate inflation, because they omit the effect of substitution between goods, changes in quality of the goods, and the impact of the availability of new products. Second, the use of a common price index may be a problem when building measures of income distribution, because it assumes that baskets are equivalent across all income groups.

In Argentina, consumption surveys are not very frequent. The last three were conducted in 1984-1985, 1996-1997, and 2004-2005, and where undertaken to update the basket in the CPI. However, the large time gap between updates may lead to significant biases, particularly if we consider the large structural changes undergone by the Argentina economy over the last 25 years (e.g., a large trade liberalization process). ${ }^{6}$ Thus, correcting for the biases produced in the CPI can change the evolution of real income, and correcting for the biases at different income levels can also change the evolution of income distribution during this period. ${ }^{7}$

These consumption surveys can be used to estimate the biases following the methodology of Costa (2001) and Hamilton (2001). In a nutshell, the methodology uses the assumption that Engel curves for food should be relatively stable. If this is the case, when the estimation of the Engel curves at different dates shows shifts, it is assumed that these correspond to CPI bias. To illustrate the point, consider two points in time between which the share of food in income declines with a stagnant earnings level. Under the assumption that the Engel curve is stable, this provides a presumption that CPI may be biased (overestimated in this case) as a falling income share is consistent with rising, not stagnant, income levels. Thus, the changes in the

\footnotetext{
5 Diewert et al. (2009) summarize the main developments of this literature and how they impacted on methodological changes in the US.

6 In many countries these surveys are annual, and basket revisions are done at higher frequencies.

7 This adjustment occurs by allowing an adjustment in household income by a specific index that considers the prices paid by that household.
} 
share, with some assumptions, may be linked to the CPI bias. Of course, the biases in the Engel curve are obtained after correcting for changes in relative prices and household characteristics.

In later work, Carvalho Filho and Chamon (2012) use semi-parametric models to extend the methodology to estimate the biases at different income levels, thus allowing to tackle the issue of income distribution.

We should clarify that in the previous work, identification was built from exploiting the differences across regions. In the case of Argentina, however, our data contained only one area (the metropolitan area of the city of Buenos Aires). Thus, our paper needs to innovate from a methodological point of view relative to the previous work, by finding a way to obtain identification when only data from one region are available, something we do using individual price indexes by household.

\subsection{Estimating CPI biases}

Following Costa (2001), the estimation strategy starts formally form the following equation:

$$
w_{i j t}=\varphi+\gamma\left(\ln P_{F j t}-\ln P_{N j t}\right)+\beta\left(\ln Y_{i j t}-\ln P_{G j t}\right)+\sum_{x} \theta_{x} X_{i j t}+\mu_{i j t}
$$

where $w_{i j t}$ is the ratio of food to non-food of household $i$, in region $j$ at time $t ; P_{F j t}$ is the true unobservable price of food in region $j$ at time $t ; P_{N j t}$ is the true and unobservable price of non-food in region $j$ at time $t ; Y_{i j t}$ is nominal income for household $i$, in region $j$ at time $t ; P_{G j t}$ is the true and unobservable general price level in region $j$ at time $t ; X_{i j t}$ is a set of control variables for household $i$, in region $j$ at time $t ; \mu_{i j t}$ is a random term; and $\phi, \gamma, \beta$, and the different $\theta_{x}$ are parameters.

If we call: $\prod_{G j t}$ is the cumulative percentage growth of the observable CPI in region $j$, since time 0 and time $t ; \prod_{F j t}$ is the cumulative percentage growth of the price of food, in region $j$, between time 0 and time $t ; \prod_{N j t}$ is the cumulative percentage growth of the price of non-food, in region $j$, between time 0 and time $t$; $E_{G j t}$ is the cumulative percentage increase in the measurement error in the CPI in region $j$, between time 0 and time $t ; E_{F j t}$ is the cumulative percentage increase in the measurement error in the price of food, in region $j$, between time 0 and time $t$; and $E_{N j t}$ is the cumulative percentage increase in the measurement error in the price of non-food, in region $j$, between time 0 and time $t$. We can rewrite (1) as

$$
\begin{aligned}
w_{i j t}= & \varphi+\gamma\left[\ln \left(1+\prod_{F j t}\right)-\ln \left(1+\prod_{N j t}\right)\right]+\beta\left[\ln Y_{i j t}-\ln \left(1+\prod_{G j t}\right)\right]_{G j 0} \\
& +\gamma\left[\ln P_{F j 0}-\ln P_{N j 0}\right]-\beta \ln P+\gamma\left[\ln \left(1+E_{F j t}\right)-\ln \left(1+E_{N j t}\right)\right] \\
& -\beta \ln \left(1+E_{G j t}\right)+\sum_{x} \theta_{x} X_{i j t}+\mu_{i j t} .
\end{aligned}
$$

If we assume that the mismeasurement does not change across regions, we can rewrite (2) as 


$$
\begin{aligned}
w_{i j t}= & \varphi+\gamma\left[\ln \left(1+\prod_{F j t}\right)-\ln \left(1+\prod_{N j t}\right)\right]+\beta\left[\ln Y_{i j t}-\ln \left(1+\prod_{G j t}\right)\right] \\
& +\sum_{j} \delta_{j} D_{j}+\sum_{t} \delta_{t} D_{t}+\sum_{x} \theta_{x} X_{i j t}+\mu_{i j t}
\end{aligned}
$$

where $D_{j}$ and $D_{t}$ are dummies by regions and period, and

$$
\begin{gathered}
\delta_{j}=\gamma\left(\ln P_{F j 0}-\ln P_{N j 0}\right)-\beta \ln P_{G j 0} \\
\delta_{t}=\gamma\left[\ln \left(1+E_{F t}\right)-\ln \left(1+E_{N t}\right)\right]-\beta \ln \left(1+E_{G t}\right) .
\end{gathered}
$$

Notice that $\delta_{t}$ is a function only of time. If we additionally assume that the biases for food and non-food items are similar, we can compute a measure of the general CPI bias from

$$
\ln \left(1+E_{G t}\right)=-\frac{\delta_{t}}{\beta} .
$$

From (6), we can compute $E_{G t}=e^{-\frac{\delta_{t}}{\beta}}-1$ which is the measurement error between real inflation and CPI inflation. $-E_{G t}$ is the cumulative bias. The assumption that the bias for food and non-food are the same is not necessarily very realistic. However, under reasonable assumptions, our measure can be considered a lower bound for the estimate. From (5)

$$
\ln \left(1+E_{G t}\right)=\frac{\gamma\left[\ln \left(1+E_{F t}\right)-\ln \left(1+E_{N t}\right)\right]}{\beta}-\frac{\delta_{t}}{\beta} .
$$

If food is a basic good with an income elasticity less than one $(\beta<0)$ and if the income effect is larger than substitution effect for food consumption $(\gamma<0),{ }^{8}$ and under the reasonable assumption that the mismeasurement in non-food is larger than in food products, the first term in (7) is negative and our bias can be considered a lower bound. In other words, our measure would be underestimating the bias in the CPI.

So far, we have just described the estimation methodology used in the previous works. However, due to data limitations, we need to introduce some changes in the estimation procedure. Argentina has relatively few consumption expenditures that are publicly available and, as we mentioned above, we only had access to the Survey of Household Expenditures of 1985/1986 (Encuesta de Gasto de los Hogares 1985/86, EGH85/86), the National Survey of Household Expenditures 1996/1997 (Encuesta Nacional de Gasto de los Hogares 1996/97, ENGH 96/97), and National Survey of Household Expenditures 2004/2005 (Encuesta Nacional de Gasto de los Hogares 2004/05, ENGH 04/05). The EGH 85/86 took place in the city of Buenos Aires and its metropolitan area. For the ENGH 2004/05, we only have data for the city of Buenos Aires.

As a result, our data include only two regions, and thus, Eq. (3) becomes

\footnotetext{
${ }^{8}$ While these are here arbitrary assumptions, they are consistent with the values estimated.
} 


$$
\begin{aligned}
w_{i j t}= & \varphi+\gamma\left[\ln \left(1+\prod_{F j t}\right)-\ln \left(1+\prod_{N j t}\right)\right]+\beta\left[\ln Y_{i t}-\ln \left(1+\prod_{G t}\right)\right] \\
& +\delta_{j} D_{j}+\sum_{t} \delta_{t} D_{t}+\sum_{x} \theta_{x} X_{i j t}+\mu_{i j t}
\end{aligned}
$$

where $D_{j}$ equals one for households belonging to the city of Buenos Aires.

In the literature, identification is obtained from regional variations, and thus, $P_{F j t}$ is the food price in region $j$, and $P_{G j t}$ is the general price index in region $j$. This gives several observations for each moment in time allowing estimating the coefficient on the time dummy. Unfortunately, we cannot follow this procedure here, because we only have price indexes for the entire sample (Buenos Aires and its metropolitan area). Even if we would have the regional price indexes, that of only two neighbor regions is clearly not good enough to identify the price relative effect and time dummy.

Fortunately, while the specification assumes two types of goods, food and nonfood, in reality, there are many goods within each of those categories. In the data, it is not feasible to compute a family specific food price index, but this is feasible for the non-food bundle. Thus, we construct a relative price between the food and nonfood baskets at the household level. More precisely, we have that

$$
\begin{gathered}
P_{F i t}=P_{F t} \\
P_{N i t}=\sum_{k} \lambda_{i k} P_{k t}
\end{gathered}
$$

where $\lambda_{i k}$ is the ratio of expenditure in item $k$ over overall spending on non-food items, for household $i$ at time $t$.

Considering that $\lambda_{i k}$ can be estimated from the individual data from the surveys, we can now rewrite (3) as

$$
\begin{aligned}
w_{i j t}= & \varphi+\gamma\left[\ln \left(1+\prod_{F t}\right)-\ln \left(1+\prod_{N i t}\right)\right]+\beta\left[\ln Y_{i t}-\ln \left(1+\prod_{G t}\right)\right] \\
& +\delta_{j} D_{j}+\sum_{t} \delta_{t} D_{t}+\sum_{x} \theta_{x} X_{i j t}+\mu_{i j t}
\end{aligned}
$$

where $\left(\prod_{N i t}\right)$ is the cumulative percentage growth of the price of non-food between time 0 and time $t$ at the household level. This equation provides the estimates, as shown in Table 3.

A consequence of this strategy, however, is that the price index estimated at the family level may be correlated with the error term of the equation, and may pose an endogeneity problem, for example, if this price level is correlated with the taste for food. To deal with this problem, an alternative is to assign an arbitrary value for $\gamma$ and then compute $w_{i j t}-\gamma\left[\ln \left(1+\prod_{F t}\right)-\ln \left(1+\prod_{N t}\right)\right]$ as the dependent variable to estimate the bias. This circumvents the need to use the individual price level altogether. However, where could we take this coefficient from? If we use the coefficient estimated in Eq. (1) from Table 3 (0.038), the total cumulative 
bias reaches $59.5 \%$, which is very similar to the $61 \%$ from Table 3 . But better still is to use an exogenous measure of this coefficient. Costa (2001) obtains a coefficient of 0.046 for the United States when identifying the effect of relative prices from differences in regions. Repeating the exercise with 0.046, the cumulative bias reaches 59.4\%. Using twice the coefficient for the United States (0.092), the cumulative bias reaches $58.9 \%$. The main reason why changes in the $\gamma$ coefficient do not significantly alter the results is that relative prices have not changed too much. Figure 2 shows the evolution of the relative price of food in terms of the general level between 1985 and 2005.

Because the price of food in terms of the CPI has fallen about $10 \%$ between the first and second surveys, and only $4 \%$ between the first and the third, to significantly alter the results, the coefficient should be extremely large. For example, to reduce the cumulative bias to half (i.e., to about $30 \%$ ), the coefficient should be more than 40 times the estimated coefficient for United States. In short, our results appear to be extremely robust, independently of the methodology adopted.

Trebon (2008) has suggested that economies of scale in each household may affect the share of food to non-food and suggests a correction based on introducing the household size interacted with the time dummies (that identify the bias). In other words, he suggests estimating

$$
\begin{aligned}
w_{i j t}= & \varphi+\gamma\left[\ln \left(1+\prod_{F t}\right)-\ln \left(1+\prod_{\text {Nit }}\right)\right]+\beta\left[\ln Y_{i t}^{p c}-\ln \left(1+\prod_{G t}\right)\right] \\
& +\delta_{j} D_{j}+\sum_{t} \delta_{t} D_{t}+\sum_{t} \psi_{t}\left(D_{t} * \text { hhsize }\right)+\sum_{x} \theta_{x} X_{i j t}+\mu_{i j t} .
\end{aligned}
$$

While Trebon finds that this correction reduced CPI biases by as much as a half relative to the findings in Costa (2001) and Hamilton (2001) for the US, Sect. 3 shows that in our case, this correction does not change things.

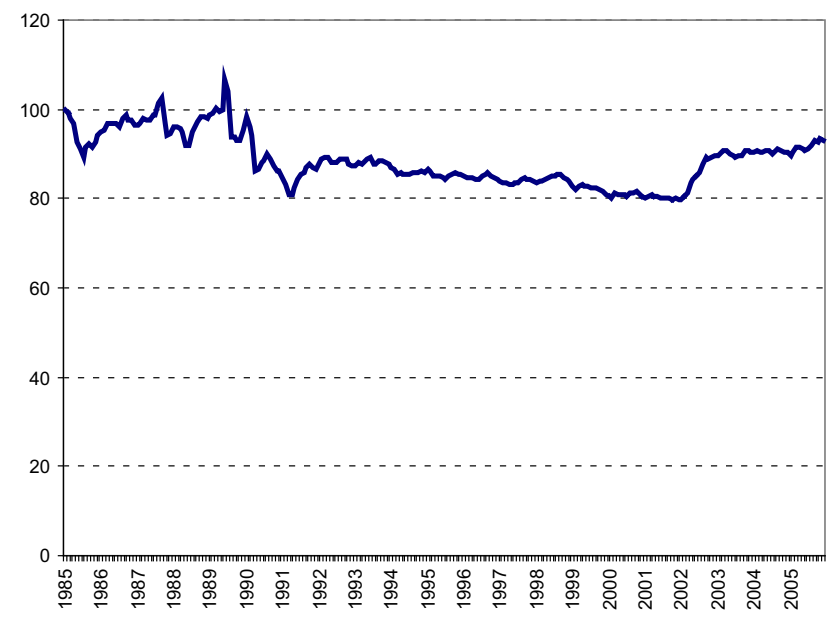

Fig. 2 Relative price of food in terms of CPI (Jan-1985 = 100). Source Own computations based on Índice de Precios al Consumidor en el Gran Buenos Aires (INDEC) 


\subsection{Income distribution effects}

Following Carvalho Filho y Chamon (2012), we explore also the possibility that the amount of bias may change along the Engel curve thus allowing estimating different mismeasurements in earnings growth for different income levels. Using a semiparametric specification and assuming, as before, that the biases are the same for the food and non-food bundles, we have that

$$
\begin{aligned}
w_{i j t}= & \varphi+\gamma\left[\ln \left(1+\prod_{F t}\right)-\ln \left(1+\prod_{\text {Nit }}\right)\right] \\
& +f_{t}\left[\ln Y_{i t}-\ln \left(1+\prod_{G t}\right)-\ln \left(1+E_{G i t}\right)\right]+\sum_{x} \theta_{x} X_{i j t}+\mu_{i j t} .
\end{aligned}
$$

The function $f_{t}\left[\ln Y_{i t}-\ln \left(1+\prod_{G t}\right)-\ln \left(1+E_{G i t}\right)\right]$ may be estimated non-parametrically using the differencing method of Yatchew (1997).To apply this method, we sort observations by income. The difference between two observations can be written as

$$
\begin{aligned}
& w_{i j t}-w_{i-1 j t}=\varphi+\gamma\left\{\left[\ln \left(1+\prod_{F t}\right)-\ln \left(1+\prod_{N i t}\right)\right]-\left[\ln \left(1+\prod_{F t}\right)-\ln \left(1+\prod_{N i-1 t}\right)\right]\right\} \\
& +f_{t}\left[\ln Y_{i t}-\ln \left(1+\prod_{G t}\right)-\ln \left(1+E_{G i t}\right)\right]-f_{t}\left[\ln Y_{i-1 t}-\ln \left(1+\prod_{G t}\right)-\ln \left(1+E_{G i-1 t}\right)\right] \\
& +\sum_{x} \theta_{x}\left(X_{i j t}-X_{i-1 j t}\right)+\mu_{i j t}-\mu_{i-1 j t} .
\end{aligned}
$$

As we have sorted by incomes, incomes are pretty similar so

$$
\ln Y_{i t}-\ln \left(1+\prod_{G t}\right)-\ln \left(1+E_{G i t}\right) \cong \ln Y_{i-1 t}-\ln \left(1+\prod_{G t}\right)-\ln \left(1+E_{G i-1 t}\right) .
$$

Assuming that $f_{t}$ is a smooth function:

$$
f_{t}\left[\ln Y_{i t}-\ln \left(1+\prod_{G t}\right)-\ln \left(1+E_{G i t}\right)\right] \cong f_{t}\left[\ln Y_{i-1 t}-\ln \left(1+\prod_{G t}\right)-\ln \left(1+E_{G i-1 t}\right)\right] .
$$

Therefore, Eq. (14) becomes 


$$
\begin{aligned}
w_{i j t}-w_{i-1 j t}= & \varphi+\gamma\left\{\left[\ln \left(1+\prod_{F t}\right)-\ln \left(1+\prod_{N i t}\right)\right]-\left[\ln \left(1+\prod_{F t}\right)-\ln \left(1+\prod_{N i-1 t}\right)\right]\right\} \\
& +\sum_{x} \theta_{x}\left(X_{i j t}-X_{i-1 j t}\right)+\mu_{i j t}-\mu_{i-1 j t} .
\end{aligned}
$$

Note that Eq. (17) is a linear function [with coefficients identical to those of (13)], so that we can consistently estimate it by OLS, and construct the linear part of the prediction of $w_{i j t}$, called $\hat{w}_{i j t}$, to arrive to

$$
w_{i j t}-\hat{w}_{i j t}=f_{t}\left[\ln Y_{i t}-\ln \left(1+\prod_{G t}\right)-\ln \left(1+E_{G i t}\right)\right]+\mu_{i j t} .
$$

If we take the right side of Eq. (18) as a dependent variable, we can estimate Eq. (18) by any common non-parametric method, and we choose to estimate it by local weighted regression method.After estimating $\hat{f}_{t}$, the cumulative bias may then be computed as the value of $E_{\text {Git }}$ that solves for each household $i$ at time $t$, the following equation:

$$
\hat{f}_{t}\left[\ln Y_{i t}-\ln \left(1+\prod_{G t}\right)-\ln \left(1+E_{G i t}\right)\right]=\hat{f}_{0}\left[\ln Y_{i t}-\ln \left(1+\prod_{G t}\right)\right] .
$$

Intuitively, we may think that if the function $f$ is constant in time, the value of $f$ for a given income level must be the same independently of the time period used for its estimation.

To estimate the cumulative bias for households at time $t$, we went through the following steps. First, we selected the real income of households at time 0 that had $\hat{f}_{0}$ near the value estimated for each household at time $t$ (that is $\hat{f}_{t}$ ). In fact, we selected two incomes at time 0 for each household at time $t$ (those with income that were immediately higher and lower in terms of $\hat{f}$ ). Second, we computed the difference in real income between the two selected households. Third, we distributed linearly the difference according to the number of households from time $t$ contained between the higher and lower bounds selected above (in terms of $\hat{f}$ ) from households at time 0 . Fourth, we computed the real income from household in time $t$ that it should have as per its share of food, adding to the income of lower (in terms of $\hat{f}$ ) the difference computed before. Fifth, we computed the bias from household $i$ at time $t$, using the real income from household at time $t$, and the real income that it should as per its share of food. More precisely, what we do is to compute

$$
E_{G i t}=\exp \left[\ln Y_{i t}-\ln \left(1+\prod_{G t}\right)-\left[\ln Y_{i 0}^{\hat{f}_{0}^{1}}+\frac{\left(\ln Y_{i 0}^{\hat{f}_{0}^{2}}-\ln Y_{i 0}^{\hat{f}_{0}^{1}}\right)}{H} * h\right]\right]-1 .
$$


Given that $Y_{i 0}^{\hat{f}_{0}^{1}}$ is the income of the household with the lowest closest $\hat{f}_{0}$ to the household $i$ at time $t$, and $Y_{i 0}^{\hat{f}_{0}^{2}}$ is the income of the household with the highest closest $\hat{f}_{0}$ to the household $i$ at time $t, \mathrm{H}$ is the number of households at time $t$ that has an $\hat{f}_{1}$ between $\hat{f}_{0}^{1}$ and $\hat{f}_{0}^{2}$ and $h=1 \ldots H$ is the order of these households sorted by $\hat{f}$.

\section{Results}

\subsection{Data}

As we mentioned above, Argentina has relatively few consumption expenditures that are publicly available. Thus, we only had access to the Survey of Household Expenditures of 1985/1986 (Encuesta de Gasto de los Hogares 1985/86, EGH85/ 86), the National Survey of Household Expenditures 1996/1997 (Encuesta Nacional de Gasto de los Hogares 1996/97, ENGH 96/97), and the National Survey of Household Expenditures 2004/2005 (Encuesta Nacional de Gasto de los Hogares 2004/05, ENGH 04/05). The EGH 85/86 took place in the city of Buenos Aires and its metropolitan area. For the ENGH 2004/05, we only have data for the city of Buenos Aires.

We start our analysis of this data in Fig. 3, with a brief illustration of some basic statistics for the three household surveys. There, we show expenditure shares on different types of goods as a function of income levels. Each curve depicts one the three surveys for which we have data.

Some straightforward conclusions may be inferred from the figure. First, the relation between food and income is negative, indicating that food is a basic good. More so, not only can we see that the share of food falls systematically as we move upwards in income, but that the shares fall for each later survey. To the extent that Engel curves are stable, this would clearly indicate that income levels increased uninterruptedly throughout the period. With the exception of housing, the shares of the remaining composite goods tend to increase with income. For a nonArgentinean, perhaps, it is surprising how much Education expenditures increase with income, a result that originates on the much higher use of private education among higher income levels.

To check the consistency and quality of the data, Table 1 shows the main demographic characteristics for each survey. The table shows that the data are fairly homogenous, but that over the period of the three surveys, Argentina has experienced a reduction in household size, a larger share of females in the labor force, and an increase in the number of single parents' households.

To compare the nominal variables, we use the CPI to bring them to a comparable basis (in the table, all prices are expressed in 1999 pesos). The table shows that, according to the data, income levels decrease quite sizably between the 85/86 wave and the 96/97 sample. Notice that during the same period (see Fig. 3), there is an unambiguous decline in the share of food for all income groups. It is this inconsistency (lower food share comes with higher, not lower income) that will be 

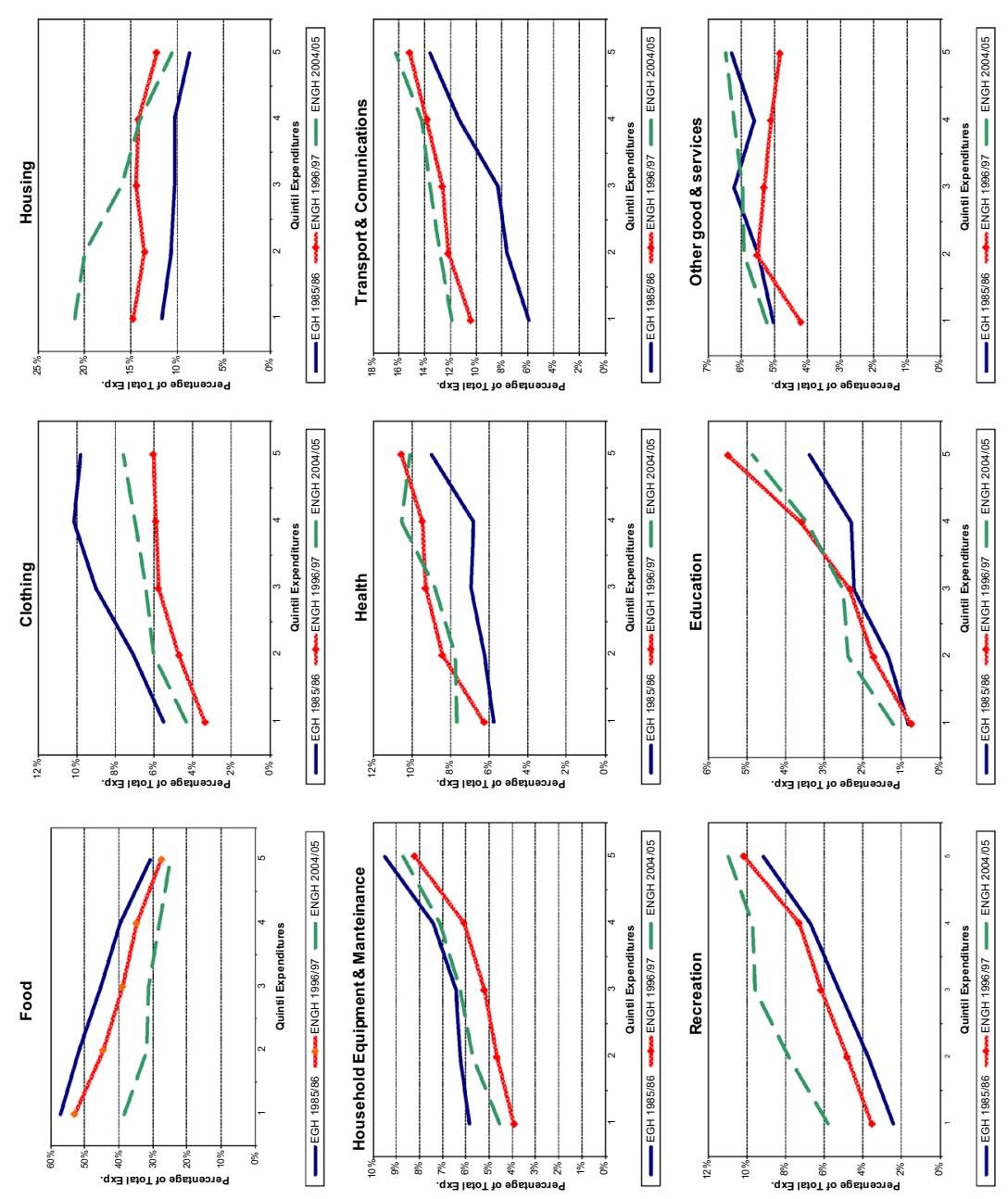

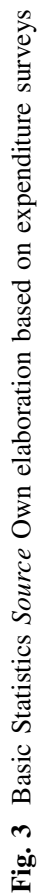




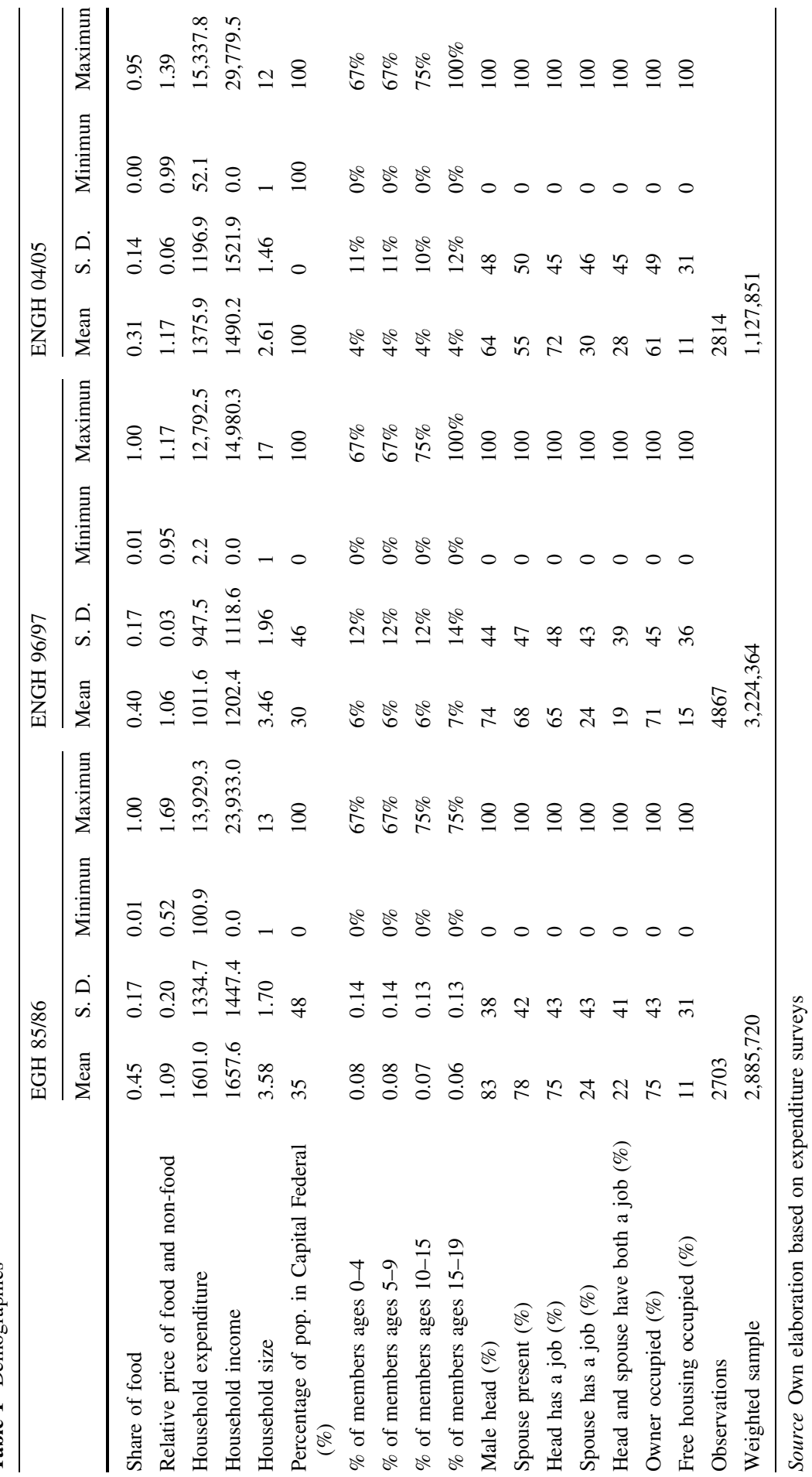


at the crux of our estimation of the CPI bias during this period. For the later period, incomes increase, while the food share continues to decline, so at this stage, it is unclear whether a bias exists or not.

Table 2 shows that data for the city of Buenos Aires only provide an even more striking finding: household income has fallen throughout in spite of declining food shares.

\subsection{Estimating biases}

To estimate the bias in CPI measurement, we use Eq. (11) which allows to estimate the magnitude (as well as the statistical significance) of the bias. The results are shown in Table 3.

Columns (1) and (4) use expenditures as a proxy for permanent income. Columns (2) and (5) use current income. Columns (3) and (6) use current income as an instrument for expenditure. The second set of regressions adds a number of additional control variables.

The table shows that if we compare the 85/86-96/97 periods, we see similar measure biases across the estimations, with a cumulative bias of the order of between 58 and $65 \%$. The large bias indicates an overestimation of the CPI of a whopping range between 7.5 and $9.2 \%$ per year. Considering that it is likely that the bias may not have occurred uniformly across years, this suggests a massive overestimation in particular years. On the contrary, when comparing the 96/97 and 04/05 periods, we find a relatively small bias, which is also, typically, not significant.

Considering the whole sample and spanning the entire democratic period, we find an average bias of between 4.3 and $5.7 \%$, indicating that real earnings may have grown by this additional amount during the period, similar to the numbers found for Brazil and much larger than the numbers found for the US.

The fact that the overestimation of the CPI takes place in the first part of the sample has to do, in our view, with the massive change occurred in Argentina as a result of the opening up of the economy in the late $80 \mathrm{~s}$ and early $90 \mathrm{~s}$. While this time dimension will have to be tested and evaluated in future work, we present here an "illustration" of the effect by showing the change in varieties of commercial retailing in Argentina between the 1980s and the 1990s. In the 1980s, varieties were minimal and the quality relatively poor. We believe that visualizing the difference may help in understanding the magnitude of the potential gain. Figure 4 shows three pictures. One corresponds to the typical grocery store in the 1980s. The shelves show how limited the variety offered was. The two other pictures show a minimarket and a large chain store supermarket ("hipermercado", as is known in Argentina) in the 2000s. While the change depicts the food component, similar changes were observed throughout this period across all consumption baskets.

One potential criticism of our results is that the food item is composed of products consumed both inside and outside the household. Since goods consumed outside home may include some service component and thus not be entirely subject to the pattern of the typical Engel curve, Table 4 shows the results using only the 


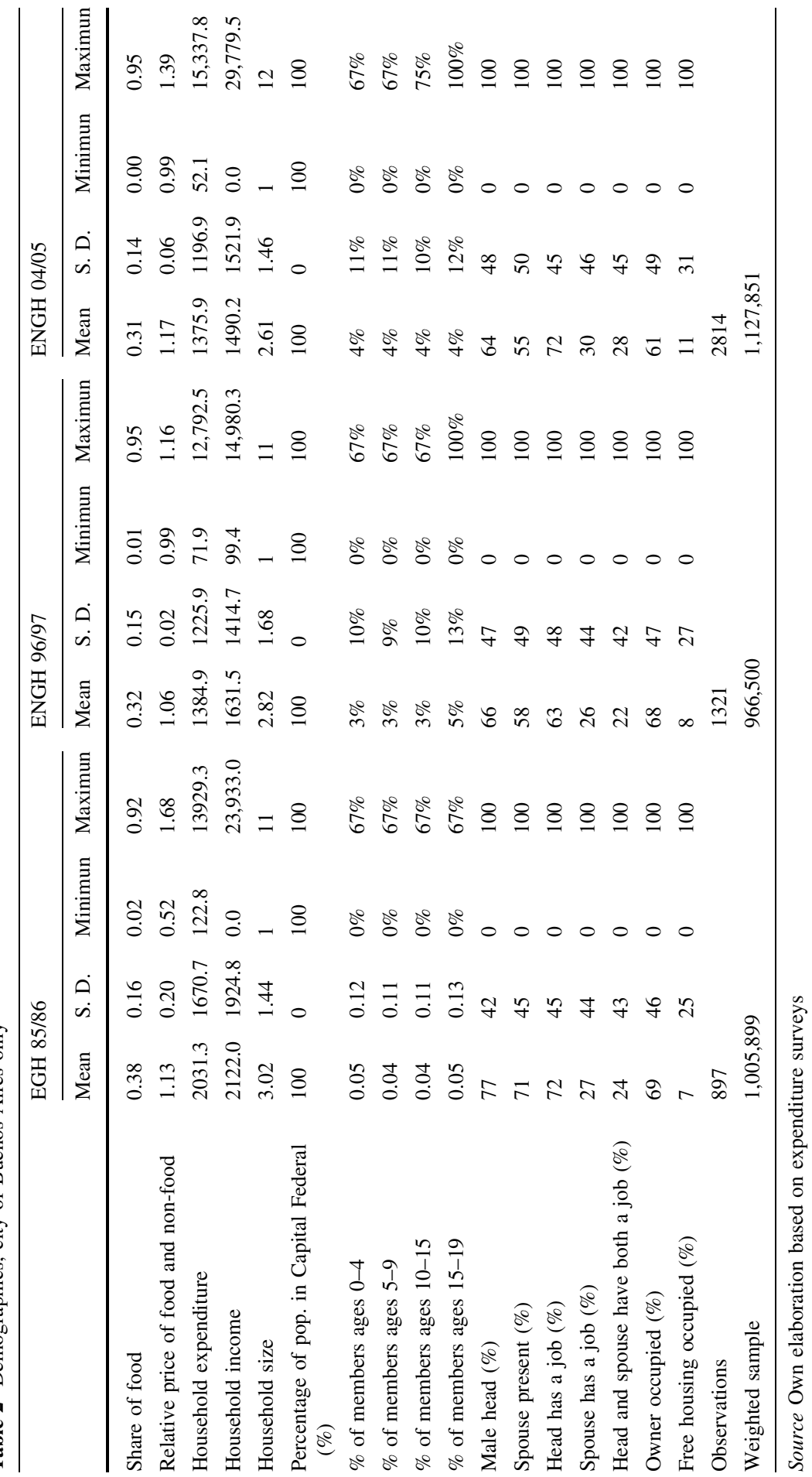


Table 3 CPI bias, robustness check

\begin{tabular}{|c|c|c|c|c|c|c|}
\hline & \multicolumn{6}{|c|}{ Dep. Var.: Share of food } \\
\hline & \multicolumn{3}{|c|}{ Small set of control variables } & \multicolumn{3}{|c|}{ Extended set of control variables } \\
\hline & $\begin{array}{l}\text { Using } \\
\text { Expenditure } \\
\text { (1) }\end{array}$ & $\begin{array}{l}\text { Using } \\
\text { Income } \\
\text { (2) }\end{array}$ & $\begin{array}{l}\text { Using } \\
\text { income as } \\
\text { instrument } \\
\text { of } \\
\text { expenditure } \\
\text { (3) }\end{array}$ & $\begin{array}{l}\text { Using } \\
\text { Expenditure } \\
\text { (4) }\end{array}$ & $\begin{array}{l}\text { Using } \\
\text { Income } \\
\text { (5) }\end{array}$ & $\begin{array}{l}\text { Using } \\
\text { income as } \\
\text { instrument } \\
\text { of } \\
\text { expenditure } \\
\text { (6) }\end{array}$ \\
\hline $\begin{array}{l}\text { Dummy for } \\
\text { ENGH } \\
96 / 97\end{array}$ & $\begin{array}{l}-0.110^{* * * *} \\
(0.004)\end{array}$ & $\begin{array}{l}-0.086^{* * *} \\
(0.004)\end{array}$ & $\begin{array}{l}-0.115^{* * *} \\
(0.004)\end{array}$ & $\begin{array}{l}-0.099 * * * \\
(0.004)\end{array}$ & $\begin{array}{l}-0.076^{* * * *} \\
(0.004)\end{array}$ & $\begin{array}{l}-0.104 * * * \\
(0.004)\end{array}$ \\
\hline $\begin{array}{l}\text { Dummy for } \\
\text { ENGH } \\
04 / 05\end{array}$ & $\begin{array}{l}-0.111^{* * *} \\
(0.005)\end{array}$ & $\begin{array}{l}-0.101 * * * \\
(0.004)\end{array}$ & $\begin{array}{l}-0.115^{* * *} \\
(0.005)\end{array}$ & $\begin{array}{l}-0.100 * * * \\
(0.005)\end{array}$ & $\begin{array}{l}-0.084 * * * \\
(0.006)\end{array}$ & $\begin{array}{l}-0.105^{* * *} \\
(0.006)\end{array}$ \\
\hline $\begin{array}{l}\text { Ln of per } \\
\text { household } \\
\text { expenditure }\end{array}$ & $\begin{array}{l}-0.118 * * * \\
(0.002)\end{array}$ & & $\begin{array}{l}-0.130 * * * \\
(0.003)\end{array}$ & $\begin{array}{l}-0.097 * * * \\
(0.003)\end{array}$ & & $\begin{array}{l}-0.108 * * * \\
(0.004)\end{array}$ \\
\hline $\begin{array}{l}\text { Ln of per } \\
\text { household } \\
\text { income }\end{array}$ & & $\begin{array}{l}-0.100^{* * *} \\
(0.003)\end{array}$ & & & $\begin{array}{l}-0.072 * * * \\
(0.003)\end{array}$ & \\
\hline $\begin{array}{l}\text { Food prices/ } \\
\text { non-food } \\
\text { prices }\end{array}$ & $\begin{array}{l}0.038 * * \\
(0.015)\end{array}$ & $\begin{array}{l}0.050 * * * \\
(0.015)\end{array}$ & $\begin{array}{l}0.032 * * \\
(0.015)\end{array}$ & $\begin{array}{l}0.046^{* * * *} \\
(0.015)\end{array}$ & $\begin{array}{l}0.061 * * * \\
(0.015)\end{array}$ & $\begin{array}{l}0.041 * * * \\
(0.015)\end{array}$ \\
\hline Observations & 10,380 & 10,364 & 10,364 & 10,380 & 10,364 & 10,364 \\
\hline R-squared & 0.407 & 0.35 & 0.405 & 0.424 & 0.382 & 0.423 \\
\hline $\begin{array}{l}\text { Adj. } \\
\text { R-squared }\end{array}$ & 0.406 & 0.349 & 0.404 & 0.421 & 0.379 & 0.420 \\
\hline $\begin{array}{l}\text { Cumulative } \\
\text { Bias in CPI } \\
\text { from } 85 / 86 \\
\text { to } 96 / 97\end{array}$ & 60.6 & 57.6 & 58.6 & 64.0 & 65.2 & 61.9 \\
\hline P. $5 \%$ & 62.5 & 60.2 & 60.5 & 66.4 & 68.6 & 64.3 \\
\hline P. $95 \%$ & 58.4 & 54.7 & 56.5 & 61.7 & 61.5 & 59.3 \\
\hline $\begin{array}{l}\text { Annual } \\
\text { Implicit } \\
\text { Bias from } \\
85 / 86 \text { to } \\
96 / 97\end{array}$ & 8.11 & 7.51 & 7.71 & 8.88 & 9.16 & 8.40 \\
\hline P. $5 \%$ & 8.53 & 8.04 & 8.10 & 9.44 & 9.98 & 8.95 \\
\hline P. $95 \%$ & 7.67 & 6.95 & 7.28 & 8.34 & 8.31 & 7.86 \\
\hline $\begin{array}{l}\text { Cumulative } \\
\text { Bias in CPI } \\
\text { from } 85 / 86 \\
\text { to } 04 / 05\end{array}$ & 61.0 & 63.5 & 58.7 & 64.4 & 69.0 & 62.3 \\
\hline P. $5 \%$ & 63.0 & 66.3 & 61.0 & 67.2 & 72.4 & 65.0 \\
\hline P. $95 \%$ & 58.3 & 60.2 & 56.0 & 60.5 & 64.5 & 58.5 \\
\hline
\end{tabular}


Table 3 continued

Dep. Var.: Share of food

Small set of control variables

\begin{tabular}{|c|c|c|}
\hline Using & Using & Using \\
\hline Expenditure & Income & $\begin{array}{l}\text { income as } \\
\text { instrument } \\
\text { of } \\
\text { expenditure }\end{array}$ \\
\hline (1) & (2) & (3) \\
\hline
\end{tabular}

Annual
Implicit
Bias from
$85 / 86$ to
$04 / 05$

\begin{tabular}{lllllll} 
P. 5\% & 4.85 & 5.30 & 4.60 & 5.42 & 6.23 & 5.11 \\
P. 95\% & 4.28 & 4.50 & 4.02 & 4.54 & 5.04 & 4.30 \\
$\begin{array}{l}\text { Cumulative } \\
\quad \text { Bias in CPI }\end{array}$ & $\mathbf{0 . 9 5}$ & $\mathbf{1 3 . 9 0}$ & $\mathbf{0 . 2 7}$ & $\mathbf{1 . 0 7}$ & $\mathbf{1 0 . 8 0}$ & $\mathbf{1 . 0 4}$ \\
from 96/97 & & & & & & \\
$\quad$ to 04/05 & & & & & & \\
P. 5\% & 7.26 & 20.00 & 6.11 & 8.73 & 19.80 & 8.14 \\
P. 95\% & -5.70 & 7.12 & -5.84 & -8.10 & 0.44 & -7.09 \\
Annual & $\mathbf{0 . 1 1}$ & $\mathbf{1 . 6 5}$ & $\mathbf{0 . 0 3}$ & $\mathbf{0 . 1 2}$ & $\mathbf{1 . 2 6}$ & $\mathbf{0 . 1 2}$ \\
$\quad$ Implicit & & & & & & \\
$\quad$ Bias from & & & & & & \\
96/97 to & & & & & & \\
$\quad 04 / 05$ & & & & & & \\
P. 5\% & 0.83 & 2.44 & 0.70 & 1.01 & 2.42 & 0.94 \\
P. 95\% & -0.62 & 0.82 & -0.63 & -0.87 & 0.05 & -0.76 \\
\hline
\end{tabular}

Bold numbers indicate bias values estimated

Notes P. 5 and P. 95\% correspond to percentile 5 and percentile 95 of 90 percent bootstrap confidence interval. Small set of control variables includes percentage of members ages $0-4$, percentage of members ages 5-9, percentage of members ages 10-15, percentage of members ages 15-19, dummies for Capital Federal, male head, spouse present, head has a job, spouse has a job, head and spouse have both a job, owner occupied and free housing occupied. Extended set of control variables includes also percentage of members ages 20-35, percentage of members ages 35-60, number of income recipients, dummies for head self-employed, head employer, household has a last one car, head is married, head is single, head unmarried with spouse, educational levels of heads, and head's job sectors. Robust standard errors in parentheses. * significant at $10 \%$; ** significant at $5 \%$; ** significant at $1 \%$

Source Own elaboration based on expenditure surveys

share of food at home as the dependent variable. As can be seen, the results are similar to those obtained previously.

Table 5 shows the results including the specification suggested by Trebon (2008), which introduces a term to take into account the effect on food shares of household size. A quick inspection of the table, however, reveals that in the case of Argentina, this also does not modify the numbers in any significant manner. 
Fig. 4 Variety in food retailing Source Stock photos

\section{Grocery store in the 80 's}

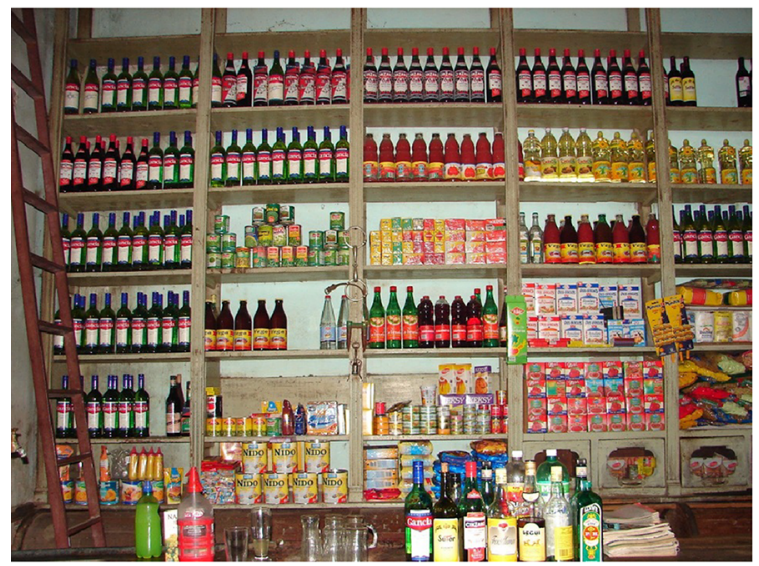

Grocery store in the 2000 's

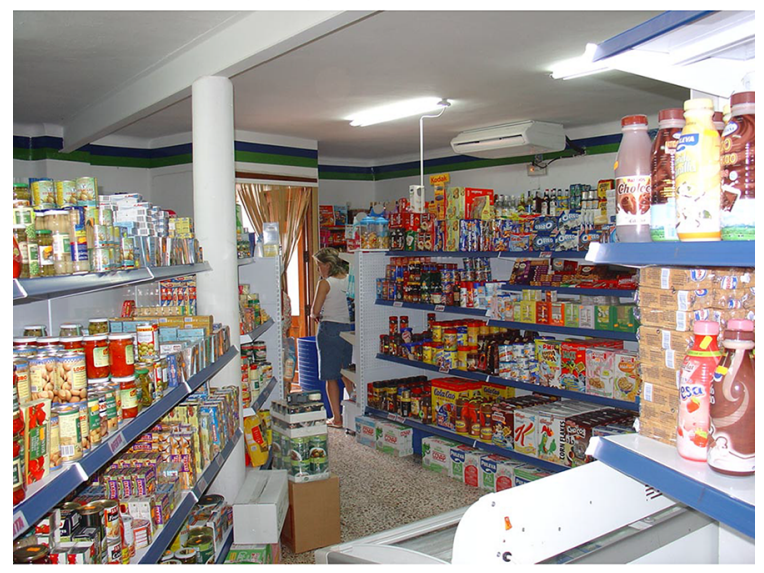

Super market in the 2000's

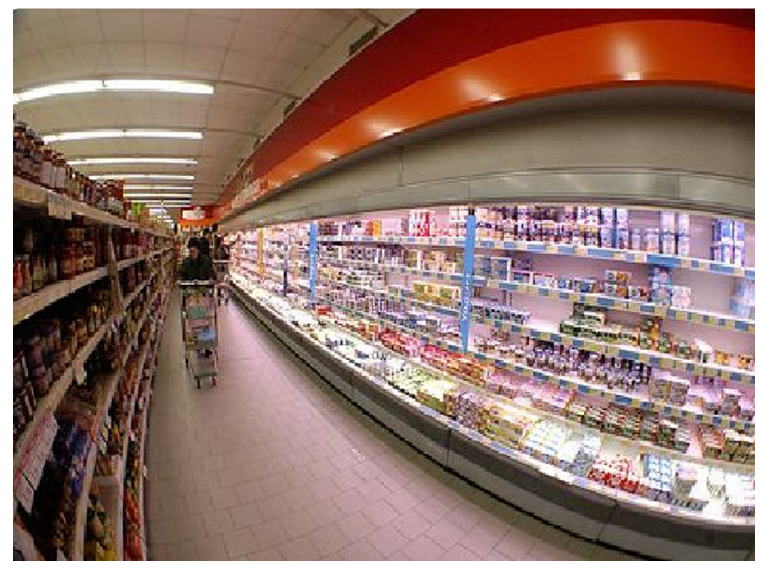


Table 4 CPI bias robustness check

\begin{tabular}{|c|c|c|c|c|c|c|}
\hline & \multicolumn{6}{|c|}{ Dep. Var.: Share of food at home } \\
\hline & \multicolumn{3}{|c|}{ Small set of control variables } & \multicolumn{3}{|c|}{ Extended set of control variables } \\
\hline & $\begin{array}{l}\text { Using } \\
\text { Expenditure }\end{array}$ & $\begin{array}{l}\text { Using } \\
\text { Income } \\
\text { (2) }\end{array}$ & $\begin{array}{l}\text { Using } \\
\text { income as } \\
\text { instrument } \\
\text { of } \\
\text { expenditure } \\
\text { (3) }\end{array}$ & $\begin{array}{l}\text { Using } \\
\text { Expenditure }\end{array}$ & $\begin{array}{l}\text { Using } \\
\text { Income } \\
\text { (5) }\end{array}$ & $\begin{array}{l}\text { Using } \\
\text { income as } \\
\text { instrument } \\
\text { of } \\
\text { expenditure } \\
\text { (6) }\end{array}$ \\
\hline $\begin{array}{l}\text { Dummy for } \\
\text { ENGH } \\
96 / 97\end{array}$ & $\begin{array}{l}-0.126^{* * *} \\
(0.004)\end{array}$ & $\begin{array}{l}-0.101 * * * \\
(0.004)\end{array}$ & $\begin{array}{l}-0.134 * * * \\
(0.004)\end{array}$ & $\begin{array}{l}-0.113^{* * *} \\
(0.004)\end{array}$ & $\begin{array}{l}-0.088 * * * \\
(0.004)\end{array}$ & $\begin{array}{l}-0.123 * * * \\
(0.004)\end{array}$ \\
\hline $\begin{array}{l}\text { Dummy for } \\
\text { ENGH } \\
04 / 05\end{array}$ & $\begin{array}{l}-0.135^{* * * *} \\
(0.005)\end{array}$ & $\begin{array}{l}-0.126^{* * * *} \\
(0.005)\end{array}$ & $\begin{array}{l}-0.142 * * * \\
(0.005)\end{array}$ & $\begin{array}{l}-0.124 * * * \\
(0.005)\end{array}$ & $\begin{array}{l}-0.108 * * * \\
(0.005)\end{array}$ & $\begin{array}{l}-0.134 * * * \\
(0.005)\end{array}$ \\
\hline $\begin{array}{l}\text { Ln of } \\
\text { household } \\
\text { expenditure }\end{array}$ & $\begin{array}{l}-0.131 * * * \\
(0.002)\end{array}$ & & $\begin{array}{l}-0.151^{* * *} \\
(0.003)\end{array}$ & $\begin{array}{l}-0.110^{* * *} \\
(0.003)\end{array}$ & & $\begin{array}{l}-0.131 * * * \\
(0.004)\end{array}$ \\
\hline $\begin{array}{l}\text { Ln of } \\
\text { household } \\
\text { income }\end{array}$ & & $\begin{array}{l}-0.116^{* * * *} \\
(0.003)\end{array}$ & & & $\begin{array}{l}-0.087 * * * \\
(0.003)\end{array}$ & \\
\hline $\begin{array}{l}\text { Food prices/ } \\
\text { non-food } \\
\text { prices }\end{array}$ & $\begin{array}{l}0.040 * * * \\
(0.015)\end{array}$ & $\begin{array}{l}0.052 * * * \\
(0.016)\end{array}$ & $\begin{array}{l}0.031 * * \\
(0.015)\end{array}$ & $\begin{array}{l}0.041 * * * \\
(0.015)\end{array}$ & $\begin{array}{l}0.056^{* * * *} \\
(0.015)\end{array}$ & $\begin{array}{l}0.031 * * \\
(0.015)\end{array}$ \\
\hline Observations & 10,380 & 10,364 & 10,364 & 10,380 & 10,364 & 10,364 \\
\hline R-squared & 0.483 & 0.432 & 0.478 & 0.503 & 0.463 & 0.499 \\
\hline $\begin{array}{l}\text { Adj. } \\
\text { R-squared }\end{array}$ & 0.482 & 0.431 & 0.478 & 0.500 & 0.460 & 0.497 \\
\hline $\begin{array}{l}\text { Cumulative } \\
\text { Bias in CPI } \\
\text { from } 85 / 86 \\
\text { to } 96 / 97(\%)\end{array}$ & 61.6 & 58.0 & 58.9 & 64.2 & 63.7 & 60.8 \\
\hline P. $5(\%)$ & 63.2 & 60.3 & 60.5 & 66.2 & 66.7 & 62.9 \\
\hline P. $95(\%)$ & 59.8 & 55.6 & 57.1 & 62.2 & 60.8 & 58.9 \\
\hline $\begin{array}{l}\text { Annual } \\
\text { Implicit Bias } \\
\text { from } 85 / 86 \\
\text { to } 96 / 97(\%)\end{array}$ & 8.33 & 7.59 & 7.77 & 8.91 & 8.81 & 8.17 \\
\hline P. $5(\%)$ & 8.69 & 8.05 & 8.09 & 9.39 & 9.52 & 8.61 \\
\hline P. $95(\%)$ & 7.94 & 7.11 & 7.40 & 8.46 & 8.15 & 7.76 \\
\hline $\begin{array}{l}\text { Cumulative } \\
\text { Bias in CPI } \\
\text { from } 85 / 86 \\
\text { to } 04 / 05\end{array}$ & 64.2 & 66.1 & 61.0 & 67.6 & 71.2 & 64.1 \\
\hline P. $5(\%)$ & 66.3 & 68.5 & 63.1 & 70.2 & 74.3 & 66.7 \\
\hline P. $95(\%)$ & 61.9 & 63.5 & 58.8 & 64.9 & 67.9 & 61.6 \\
\hline
\end{tabular}


Table 4 continued

Dep. Var.: Share of food at home

\begin{tabular}{|c|c|c|c|c|c|c|}
\hline & \multicolumn{3}{|c|}{ Small set of control variables } & \multicolumn{3}{|c|}{ Extended set of control variables } \\
\hline & $\begin{array}{l}\text { Using } \\
\text { Expenditure } \\
\text { (1) }\end{array}$ & $\begin{array}{l}\text { Using } \\
\text { Income } \\
\text { (2) }\end{array}$ & $\begin{array}{l}\text { Using } \\
\text { income as } \\
\text { instrument } \\
\text { of } \\
\text { expenditure } \\
\text { (3) }\end{array}$ & $\begin{array}{l}\text { Using } \\
\text { Expenditure } \\
\text { (4) }\end{array}$ & $\begin{array}{l}\text { Using } \\
\text { Income } \\
\text { (5) }\end{array}$ & $\begin{array}{l}\text { Using } \\
\text { income as } \\
\text { instrument } \\
\text { of } \\
\text { expenditure } \\
\text { (6) }\end{array}$ \\
\hline $\begin{array}{l}\text { Annual } \\
\text { Implicit Bias } \\
\text { from } 85 / 86 \\
\text { to } 04 / 05(\%)\end{array}$ & 5.00 & 5.26 & 4.60 & 5.48 & 6.03 & 5.00 \\
\hline P. $5(\%)$ & 5.29 & 5.62 & 4.86 & 5.87 & 6.58 & 5.35 \\
\hline P. $95(\%)$ & 4.72 & 4.91 & 4.34 & 5.11 & 5.53 & 4.67 \\
\hline $\begin{array}{l}\text { Cumulative } \\
\text { Bias in CPI } \\
\text { from } 96 / 97 \\
\text { to } 04 / 05\end{array}$ & 6.69 & 19.20 & 5.03 & 9.62 & 20.60 & 8.42 \\
\hline P. $5(\%)$ & 11.50 & 24.20 & 9.20 & 16.40 & 27.90 & 14.40 \\
\hline P. $95(\%)$ & 0.80 & 13.60 & -0.26 & 2.05 & 12.00 & 2.12 \\
\hline $\begin{array}{l}\text { Annual } \\
\text { Implicit Bias } \\
\text { from } 96 / 97 \\
\text { to } 04 / 05(\%)\end{array}$ & 0.77 & 2.34 & 0.57 & 1.12 & 2.53 & 0.97 \\
\hline P. $5(\%)$ & 1.35 & 3.03 & 1.07 & 1.97 & 3.57 & 1.71 \\
\hline P. $95(\%)$ & 0.09 & 1.61 & -0.03 & 0.23 & 1.41 & 0.24 \\
\hline
\end{tabular}

Bold numbers indicate bias values estimated

Notes P. 5 and P. 95\% correspond to percentile 5 and percentile 95 of 90 percent bootstrap confidence interval. Small set of control variables includes percentage of members ages $0-4$, percentage of members ages 5-9, percentage of members ages 10-15, percentage of members ages 15-19, dummies for Capital Federal, male head, spouse present, head has a job, spouse has a job, head and spouse have both a job, owner occupied and free housing occupied. Extended set of control variables includes also percentage of members ages 20-35, percentage of members ages 35-60, number of income recipients, dummies for head self-employed, head employer, household has a last one car, head is married, head is single, head unmarried with spouse, educational levels of heads, and head's job sectors. Robust standard errors in parentheses. * significant at $10 \%$; * significant at $5 \%$; *** significant at $1 \%$

Source Own elaboration based on expenditure surveys

An additional robustness test includes using only the data for the city of Buenos Aires. The results are similar to those estimated previously, and for brevity are not shown here.

\subsection{Income distribution effects}

The Engel curve that we estimate in the parametric version of Eqs. (11) and (12) assumes that the bias is the same across all income levels. If so, the bias is by definition constrained to be neutral from an income distribution point of view. However, this may 
Table 5 Trebon critique

\begin{tabular}{|c|c|c|c|c|c|c|}
\hline & \multicolumn{3}{|c|}{ Dep. Var.: Share of food } & & & \\
\hline & \multicolumn{3}{|c|}{ Small set of control variables } & \multicolumn{3}{|c|}{ Extended set of control variables } \\
\hline & $\begin{array}{l}\text { Using } \\
\text { expenditure }\end{array}$ & $\begin{array}{l}\text { Using } \\
\text { income }\end{array}$ & $\begin{array}{l}\text { Using } \\
\text { income as } \\
\text { instrument } \\
\text { of } \\
\text { expenditure } \\
\text { (3) }\end{array}$ & $\begin{array}{l}\text { Using } \\
\text { expenditure }\end{array}$ & $\begin{array}{l}\text { Using } \\
\text { income } \\
\text { (5) }\end{array}$ & $\begin{array}{l}\text { Using } \\
\text { income as } \\
\text { instrument } \\
\text { of } \\
\text { expenditure } \\
\text { (6) }\end{array}$ \\
\hline $\begin{array}{l}\text { Dummy for } \\
\text { ENGH 96/97 }\end{array}$ & $\begin{array}{l}-0.111^{* * * *} \\
(0.009)\end{array}$ & $\begin{array}{l}-0.093 * * * \\
(0.009)\end{array}$ & $\begin{array}{l}-0.114 * * * \\
(0.009)\end{array}$ & $\begin{array}{l}-0.101^{* * * *} \\
(0.009)\end{array}$ & $\begin{array}{l}-0.082 * * * \\
(0.009)\end{array}$ & $\begin{array}{l}-0.104 * * * \\
(0.009)\end{array}$ \\
\hline $\begin{array}{l}\text { Dummy for } \\
\text { ENGH 04/05 }\end{array}$ & $\begin{array}{l}-0.123 * * * \\
(0.009)\end{array}$ & $\begin{array}{l}-0.112 * * * \\
(0.009)\end{array}$ & $\begin{array}{l}-0.125 * * * \\
(0.009)\end{array}$ & $\begin{array}{l}-0.113 * * * \\
(0.009)\end{array}$ & $\begin{array}{l}-0.097 * * * \\
(0.010)\end{array}$ & $\begin{array}{l}-0.116^{* * *} \\
(0.009)\end{array}$ \\
\hline $\begin{array}{l}\text { Ln of per } \\
\text { capita } \\
\text { expenditure }\end{array}$ & $\begin{array}{l}-0.118^{* * *} \\
(0.002)\end{array}$ & & $\begin{array}{l}-0.130^{* * *} \\
(0.003)\end{array}$ & $\begin{array}{l}-0.097 * * * \\
(0.003)\end{array}$ & & $\begin{array}{l}-0.107^{* * * *} \\
(0.004)\end{array}$ \\
\hline $\begin{array}{l}\text { Ln of per } \\
\text { capita } \\
\text { income }\end{array}$ & & $\begin{array}{l}-0.100 * * * \\
(0.003)\end{array}$ & & & $\begin{array}{l}-0.071 * * * \\
(0.003)\end{array}$ & \\
\hline $\begin{array}{l}\text { Food prices/ } \\
\text { non-food } \\
\text { prices }\end{array}$ & $\begin{array}{l}0.037 * * \\
(0.015)\end{array}$ & $\begin{array}{l}0.048 * * * \\
(0.016)\end{array}$ & $\begin{array}{l}0.032 * * \\
(0.015)\end{array}$ & $\begin{array}{l}0.045 * * * \\
(0.015)\end{array}$ & $\begin{array}{l}0.058 * * * \\
(0.016)\end{array}$ & $\begin{array}{l}0.040 * * * \\
(0.015)\end{array}$ \\
\hline $\begin{array}{l}\text { (Dummy for } \\
\text { ENGH } \\
\text { 96/07) *(Ln } \\
\text { household } \\
\text { size) }\end{array}$ & $\begin{array}{l}0.001 \\
(0.007)\end{array}$ & $\begin{array}{l}0.006 \\
(0.007)\end{array}$ & $\begin{array}{l}(0.001) \\
(0.007)\end{array}$ & $\begin{array}{l}0.002 \\
(0.007)\end{array}$ & $\begin{array}{l}0.006 \\
(0.007)\end{array}$ & $\begin{array}{l}0.000 \\
(0.007)\end{array}$ \\
\hline $\begin{array}{l}\text { (Dummy for } \\
\text { ENGH } \\
\text { 04/05) * (Ln } \\
\text { household } \\
\text { size) }\end{array}$ & $\begin{array}{l}0.015^{* *} \\
(0.008)\end{array}$ & $\begin{array}{l}0.012 \\
(0.008)\end{array}$ & $\begin{array}{l}0.012 * \\
(0.008)\end{array}$ & $\begin{array}{l}0.016 * * \\
(0.008)\end{array}$ & $\begin{array}{l}0.016 * * \\
(0.008)\end{array}$ & $\begin{array}{l}0.014 * \\
(0.008)\end{array}$ \\
\hline Observations & 10,380 & 10,364 & 10,364 & 10,380 & 10,364 & 10,364 \\
\hline R-squared & 0.407 & 0.35 & 0.405 & 0.424 & 0.382 & 0.423 \\
\hline $\begin{array}{l}\text { Adj. } \\
\text { R-squared }\end{array}$ & 0.406 & 0.349 & 0.404 & 0.421 & 0.379 & 0.420 \\
\hline $\begin{array}{l}\text { Cumulative } \\
\text { Bias in CPI } \\
\text { from } 85 / 86 \\
\text { to } 96 / 97(\%)\end{array}$ & 61.2 & 60.3 & 58.2 & 65.0 & 68.4 & 62.2 \\
\hline P. $5(\%)$ & 65.9 & 66.0 & 62.9 & 70.3 & 74.6 & 67.2 \\
\hline P. $95(\%)$ & 56.5 & 54.3 & 53.6 & 59.9 & 61.4 & 56.9 \\
\hline $\begin{array}{l}\text { Annual } \\
\text { Implicit Bias } \\
\text { from } 85 / 86 \\
\text { to } 96 / 97(\%)\end{array}$ & 8.24 & 8.06 & 7.63 & 9.11 & 9.94 & 8.46 \\
\hline P. $5(\%)$ & 9.33 & 9.34 & 8.62 & 10.50 & 11.70 & 9.63 \\
\hline P. $95(\%)$ & 7.28 & 6.88 & 6.74 & 7.96 & 8.30 & 7.36 \\
\hline
\end{tabular}


Table 5 continued

Dep. Var.: Share of food

Small set of control variables

\begin{tabular}{lll}
\hline Using & Using & Using \\
expenditure & income & income as \\
& & instrument \\
& of \\
& & expenditure
\end{tabular}

(1)

Cumulative
Bias in CPI
from $85 / 86$
to $04 / 05(\%)$

64.9

68.7

60.8

5.10

Annual

Implicit Bias

rom 85/86

to $04 / 05(\%)$

(2) (3)

Extended set of control variables

\begin{tabular}{lll}
\hline Using & Using & Using \\
expenditure & income & income as \\
& & instrument \\
& of \\
& & expenditure
\end{tabular}

(5)

(6)

66.2

70.6

61.0

$\begin{array}{lll}64.2 & 67.7 & 61.0 \\ \mathbf{5 7 0} & \mathbf{6 . 5 8} & \mathbf{5 . 2 8}\end{array}$

$\begin{array}{lllll}5.42 & 4.70 & 5.70 & 6.58 & 5.28\end{array}$

5.64

\subsection{0}

5.21

6.40

7.56

5.93

4.71

4.20

5.01

5.49

4.60

17.30

8.62

11.60

18.90

10.60

Bias in CPI

from 96/97

to $04 / 05(\%)$

\begin{tabular}{lllllll} 
P. 5 $(\%)$ & 16.50 & 25.10 & 14.90 & 20.60 & 30.00 & 18.70 \\
P. 95 $(\%)$ & -1.43 & 4.99 & -1.33 & -2.25 & 0.61 & -1.89 \\
Annual & $\mathbf{1 . 1 3}$ & $\mathbf{2 . 0 9}$ & $\mathbf{1 . 0 0}$ & $\mathbf{1 . 3 6}$ & $\mathbf{2 . 3 0}$ & $\mathbf{1 . 2 3}$ \\
$\quad \begin{array}{l}\text { Implicit Bias } \\
\text { from 96/97 }\end{array}$ & & & & & \\
$\quad$ to 04/05 $(\%)$ & & & & & \\
P. 5 $(\%)$ & 1.99 & 3.16 & 1.78 & 2.54 & 3.88 & 2.28 \\
P. 95 $(\%)$ & -0.16 & 0.57 & -0.15 & -0.25 & 0.07 & -0.21 \\
\hline
\end{tabular}

Bold numbers indicate bias values estimated

Notes P. 5 and P. 95\% correspond to percentile 5 and percentile 95 of 90 percent bootstrap confidence interval. Small set of control variables includes percentage of members ages $0-4$, percentage of members ages 5-9, percentage of members ages 10-15, percentage of members ages 15-19, dummies for Capital Federal, male head, spouse present, head has a job, spouse has a job, head and spouse have both a job, owner occupied and free housing occupied. Extended set of control variables includes also percentage of members ages 20-35, percentage of members ages 35-60, number of income recipients, dummies for head self-employed, head employer, household has a last one car, head is married, head is single, head unmarried with spouse, educational levels of heads, and head's job sectors. Robust standard errors in parentheses. * significant at $10 \%$; ** significant at 5\%; *** significant at $1 \%$. Source: Own elaboration based on expenditure surveys

not be the case. Thus, the more flexible estimation procedure (such as the nonparametric estimation of Yatchew 1997, explained in Income distribution effects Section) allows to test the validity of this assumption, permitting for an estimation of an Engel curve shift that may differ at different income levels. 
Using share of Food

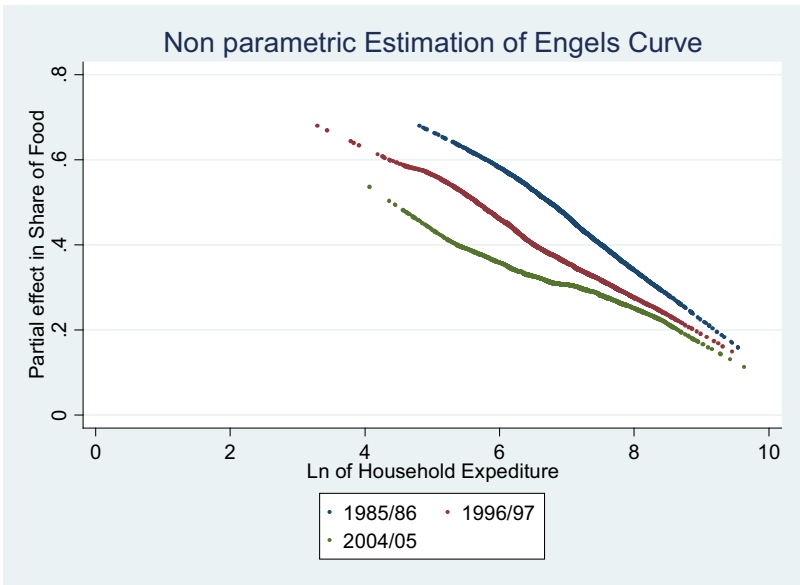

Using share of Food at home

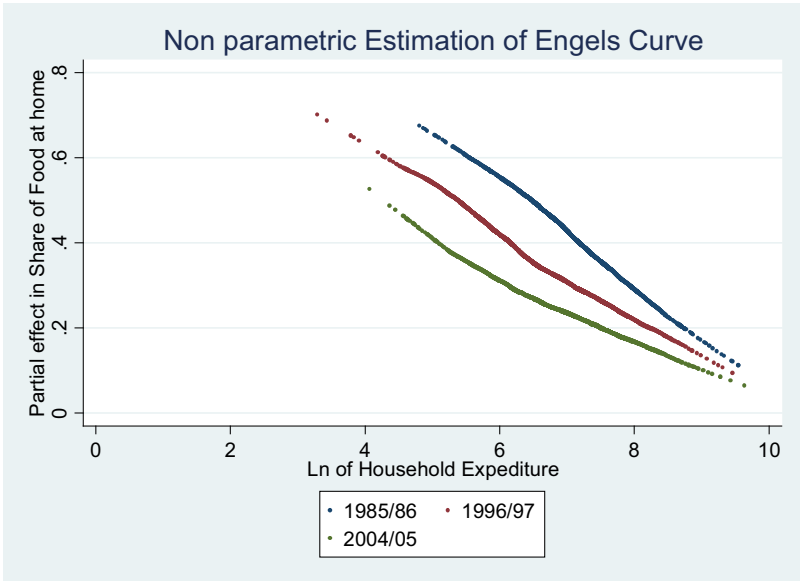

Fig. 5 Individual effects (log version) Source Own elaboration based on expenditure surveys

The result of this more flexible estimation procedure, shown in Figs. 5 and 6, confirms that, in fact, the biases are dramatically different across income levels, being much larger at lower income levels, as shown by the much larger movement in the curve at the lower part of the scale. Figure 5 shows the estimated Engel curves in log terms, whereas Fig. 6 relates the bias to income levels directly.

This result is similar to the one obtained by Carvalho Filho and Chamon (2012) for Brazil.

As we mention in the methodological section, once we compute the bias at different income levels, we can estimate an adjusted income (see Eq. 15). Table 6 shows the basic statistics for the bias in real income measures, at each income level, when comparing the base year with the two following periods. 
Using share of Food

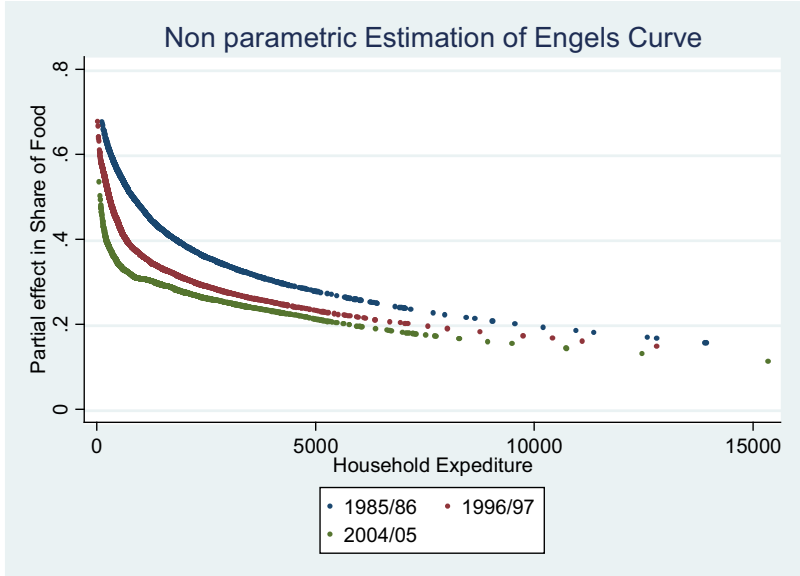

Using share of Food at home

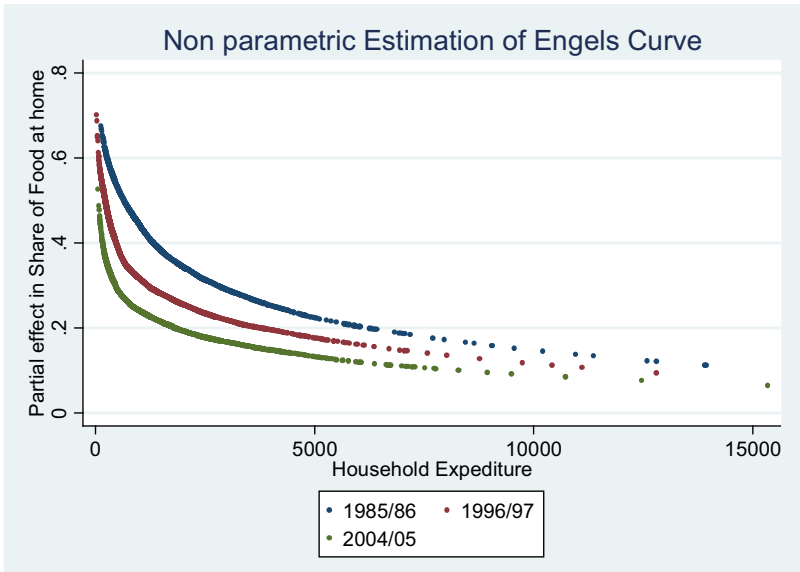

Fig. 6 Individual effects Source Own elaboration based on expenditure surveys

On average, the bias estimated is fairly similar, though somewhat larger, to that obtained in Tables 3, 4, and 5. However, as can be seen in Table 6, this average hides a large heterogeneity across income levels.

Once we compute the bias, we can correct individual income levels using individual biases. Thus, we re-estimate the corrected income using the formula:

$$
R Y *_{i t}=\frac{R Y_{i t}}{\left(1+E_{i t}\right)}
$$

where $R Y_{i t}=\frac{Y_{i t}}{\left(1+\prod_{G t}\right)}$ is the real income, and $R Y *_{i t}$ is the bias-corrected real income. While we can compute $E_{i t}$ only for the common support area, ${ }^{9}$ we use the

\footnotetext{
9 That is, the range that we have observations for at time 0 and $t$.
} 
Table 6 Biases by income level

\begin{tabular}{|c|c|c|c|c|c|c|c|}
\hline \multicolumn{4}{|c|}{ Bias using share of food } & \multicolumn{4}{|c|}{ Bias using share of food at home } \\
\hline \multicolumn{2}{|l|}{$1996 / 97$} & \multicolumn{2}{|l|}{$2004 / 05$} & \multicolumn{2}{|l|}{ 1996/97 } & \multicolumn{2}{|l|}{$2004 / 05$} \\
\hline Mean & $59.7 \%$ & Mean & $72.4 \%$ & Mean & $60.0 \%$ & Mean & $76.0 \%$ \\
\hline SD & 7.9 & $\mathrm{SD}$ & $11.0 \%$ & $\mathrm{SD}$ & $7.2 \%$ & SD & $7.2 \%$ \\
\hline Minimun & $78.8 \%$ & Minimun & $90.5 \%$ & Minimun & $71.6 \%$ & Minimun & $89.0 \%$ \\
\hline Maximun & $16.2 \%$ & Maximun & $39.1 \%$ & Maximun & $27.2 \%$ & Maximun & $51.4 \%$ \\
\hline \multicolumn{2}{|l|}{ Percentiles } & \multicolumn{2}{|c|}{ Percentiles } & \multicolumn{2}{|c|}{ Percentiles } & \multicolumn{2}{|c|}{ Percentiles } \\
\hline 5 & $67.8 \%$ & 5 & $87.2 \%$ & 5 & $66.8 \%$ & 5 & $86.1 \%$ \\
\hline 10 & $66.6 \%$ & 10 & $85.2 \%$ & 10 & $66.5 \%$ & 10 & $84.7 \%$ \\
\hline 25 & $64.3 \%$ & 25 & $81.5 \%$ & 25 & $64.5 \%$ & 25 & $81.9 \%$ \\
\hline 50 & $62.6 \%$ & 50 & $74.3 \%$ & 50 & $63.2 \%$ & 50 & $76.8 \%$ \\
\hline 75 & $56.2 \%$ & 75 & $64.7 \%$ & 75 & $56.8 \%$ & 75 & $71.0 \%$ \\
\hline 90 & $48.4 \%$ & 90 & $57.8 \%$ & 90 & $49.2 \%$ & 90 & $66.7 \%$ \\
\hline 95 & $44.5 \%$ & 95 & $51.8 \%$ & 95 & $45.3 \%$ & 95 & $62.4 \%$ \\
\hline
\end{tabular}

Source Own elaboration based on expenditure surveys
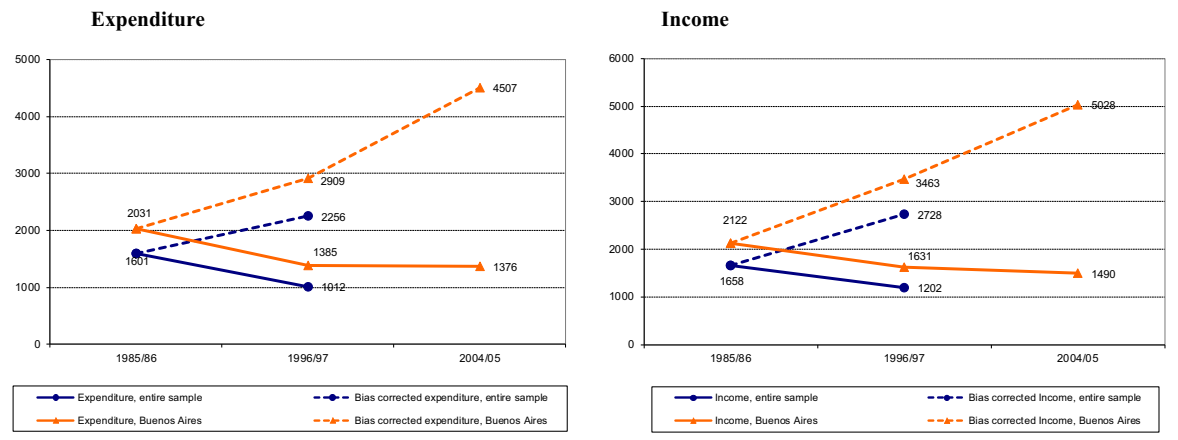

Fig. 7 Corrected income levels (mean values). Note: values are obtained taking 1985-1986 as bench mark and adjusting 1996-1997 and 2004-2005 incomes/expenditures by the corrected increase in purchasing power Source Own elaboration based on expenditure surveys

minimum (maximum) value of $E_{i t}$ to correct real income in observations at time $t$ that have a real income higher (lower) than the maximum (minimum) real income in the common support area. ${ }^{10}$

Figure 7 shows the mean values for income and expenditure deflated after correcting for the bias in the CPI. ${ }^{11}$ In the figure, we show the numbers taking 85-86 as base years. While the official data show a declining real income, adjusting for

\footnotetext{
10 This procedure can underestimate the effect of bias correction in incomes because we have seen that the bias is decreasing in income. However, there are only a few observations outside the common support area, so we do not expect this to change the results in any significant way.

11 The bias used to correct incomes and expenditures is the one that uses expenditure as approximation to permanent income in the semi-parametric estimation.
} 
Gini of Expenditure

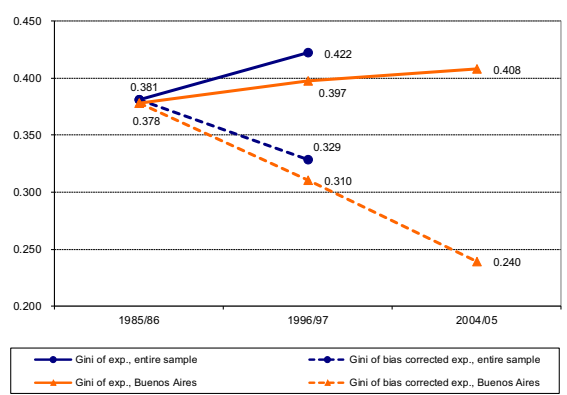

Gini of Income

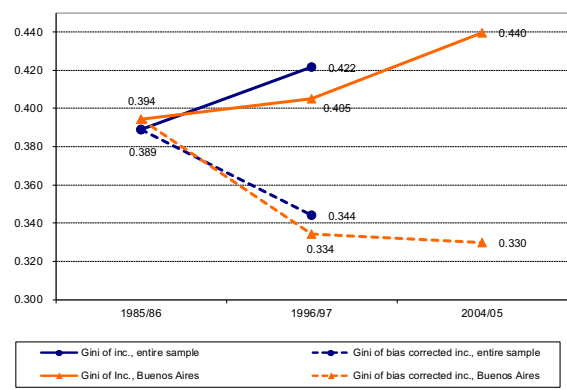

Fig. 8 Corrected Gini coefficients Source Own elaboration based on expenditure surveys

real purchasing power shows a significant increase in average real expenditure and income.

Figure 8 shows the Gini coefficients both for the official numbers and for those computed using the corrected real income numbers. Again, we take as benchmark the $85-86$ values. It is important to notice that we are not making a statement on the actual level of inequality (had we taken the 2005-2006 period as benchmark, the corrected value of the Gini would have coincided with the official numbers for these years), but we are making a statement on the fact that during the 85-2006 period, we find a sizable reduction in income inequality in Argentina, which, again, contrasts starkly with official figures.

Figure 9 shows Lorenz Curves and the bias-corrected versions for the 1996/1997 (left column) period and the 2004/2005 (right column) period, both for income (first row) and expenditures (second row). We can see that bias-corrected curves strictly dominate not corrected curves, so we can reproduce the same results of Fig. 9 using any inequality index.

To complete this presentation of our findings, Fig. 10 mimics the same graphs, but for the distribution of income and expenditure levels (left and right columns, respectively), comparing the original data with the bias-corrected data (upper and lower rows, respectively).

\section{Conclusions}

This paper has estimated the CPI measurement bias for Argentina during its recent democratic period. While we use a methodology that unveils the bias from the inconsistencies between the assumption of stable Engel curves and the evolution of the share of food in expenditures, we innovate in that we obtain identification from individual differences in the consumption bundles and price indexes at the household level, thus being able to estimate the bias with data from only one region, something that had not been done in previous work. 
Income Inequality
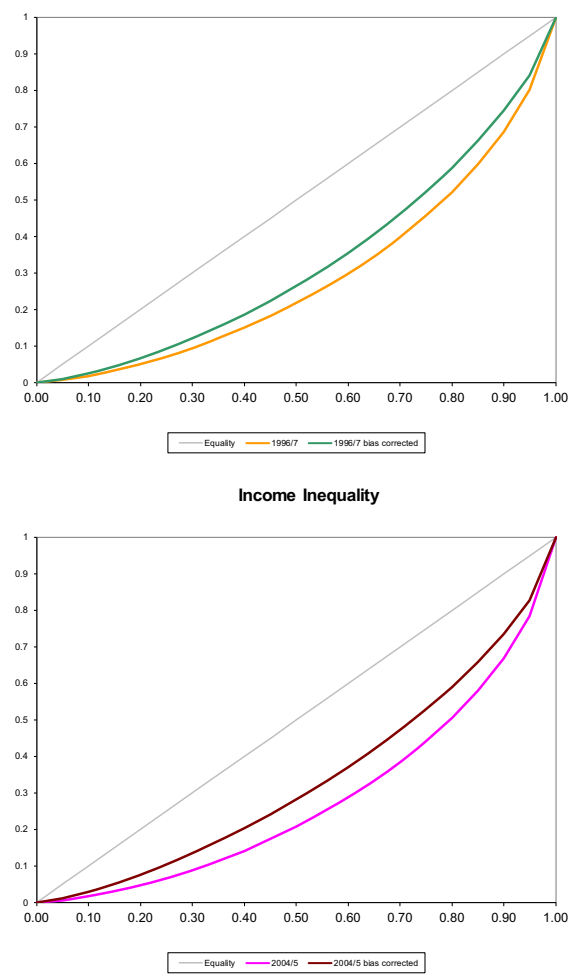

Expenditure Inequality
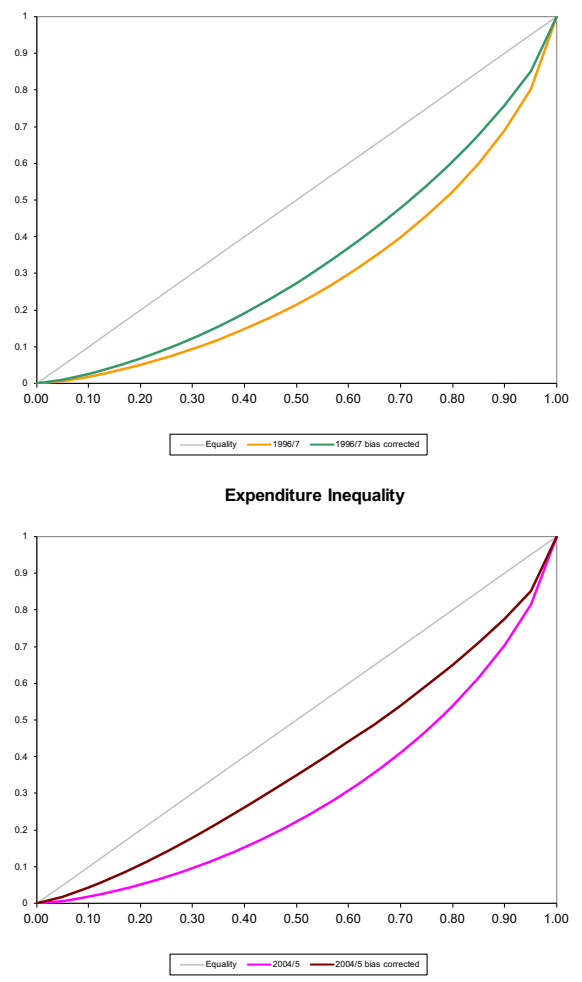

Fig. 9 Original and modified Lorenz curves Source Own elaboration based on expenditure surveys

The findings are striking. Argentina's democracy has experienced a larger (much larger) raise in real expenditure levels than previously thought, and has improved its income distribution.

The bias in expenditure levels arises primarily between 84/85 and 96/97. It is difficult with further data to estimate when the bias may be originating. The years $84 / 85$ were a time of very high inflation; thus, the data may be underestimating the level of regressivity in the income distribution those years. In addition, the late $80 \mathrm{~s}$ and early 90 s showed a period of significant opening up of the economy that led to a significant increase in income levels. Because openness comes with large changes in the quantity and quality of available products, it is not surprising that during this period, we may have experienced substantial increases in economic well-being not fully reflected in the standard statistics.

The second period is a bit more puzzling. While the data suggest an overestimation of the CPI, the level of this overestimation appears to be small. However, the bias in income distribution appears to be larger. This is puzzling, because the later period sees a rising inflation, indicating, a priori, that there should be deterioration in the income distribution levels.

All in all, our conclusion, however, is that Argentina's democracy has allowed for a much brighter performance in economic terms than it is usually credited for. Far from 

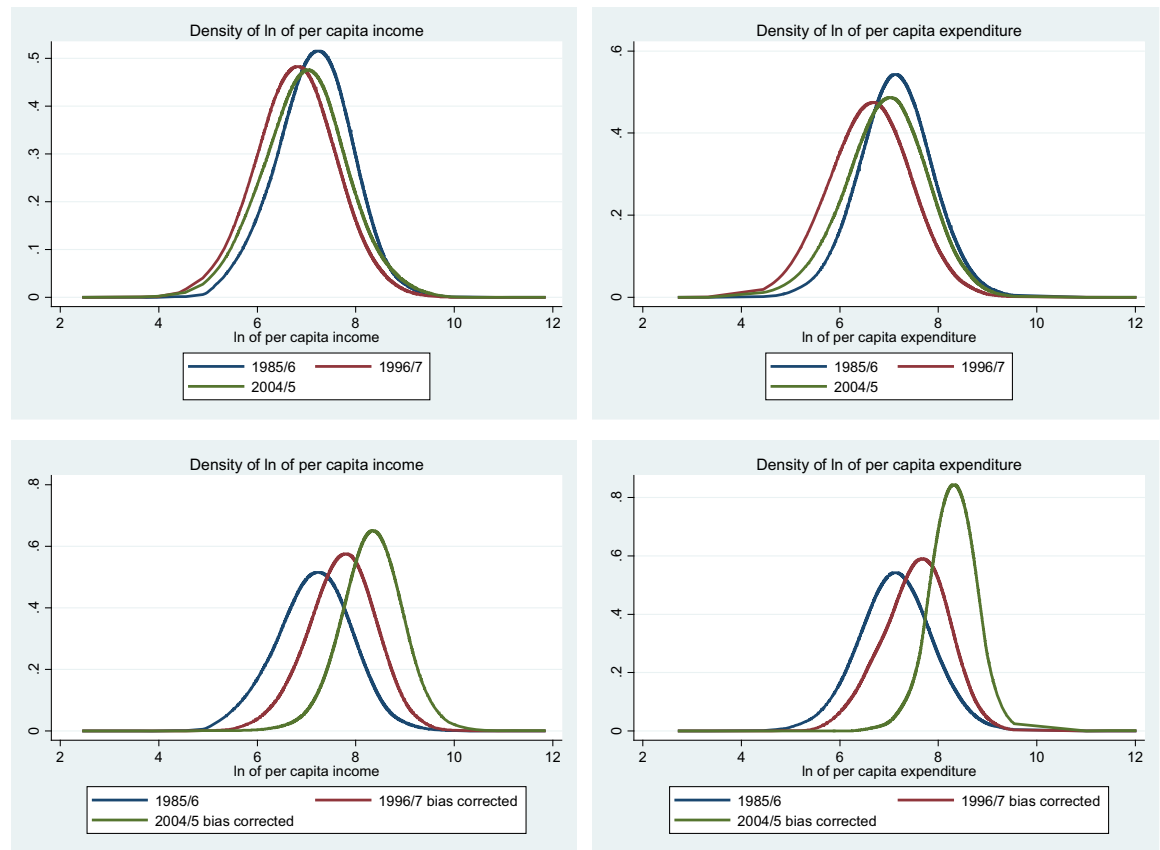

Fig. 10 Income distribution. Note: values are obtained taking 1985-1986 as bench mark and adjusting 1996-1997 and 2004-2005 incomes by the corrected increase in purchasing power Source Own elaboration based on expenditure surveys

the typical pessimism that permeates the recollection of Argentina's history and Argentina's present, we provide an optimistic view of the last 25 years, which we hope will be the beginning of a brighter XXIst century for the country and the region.

Open Access This article is distributed under the terms of the Creative Commons Attribution 4.0 International License (http://creativecommons.org/licenses/by/4.0/), which permits unrestricted use, distribution, and reproduction in any medium, provided you give appropriate credit to the original author(s) and the source, provide a link to the Creative Commons license, and indicate if changes were made.

\section{Appendix A: The data}

To run our estimations, we use the individual data points for the (EGH 85/68), (ENGH 96/97), and (ENGH 04/05) constructed by the Instituto Nacional de Estadísticas y Censos (INDEC). The EGH 85/86 covers only the city of Buenos Aires and its metropolitan area. As a result, we only considered the same region for the ENGH 96/97. For the ENGH 04/05, we only had access to the data for the city of Buenos Aires. This appears to have no fundamental effect on our estimations. Running all the estimates just for data from the city of Buenos Aires gives virtually identical results.

The price index used is the CPI for the greater Buenos Aires area, $1999=100$. 
The EGH 85/86, ENGH 96/97, and ENGH 04/05 provide data for 2717, 4907 years 2841 households each, ${ }^{12}$ reporting income and expenditures (itemized by groups) as well as the typical demographic characteristics.

Because the INDEC does not provide information about inconsistent observations in the survey, we keep out of the analysis a few observations that seem to be inconsistent in expenditure. We take out households that:

- Do not report total expenditure or report a negative value (1 in EGH 85/86, 6 in ENGH 96/97 and 10 in ENGH 04/05).

- Report a very low total expenditure (lower than 100 pesos of 1999) and a share of food lower than 50\% (19 in ENGH 96/97 and 3 in ENGH 04/05).

- Do not report expenditures in food (26 in EGH 85/86, 49 in ENGH 96/97 and 31 in ENGH 04/05).

In addition, we found 58 households in ENGH 96/97 and 93 households in ENGH $04 / 05$, with negative consumption in at least one expenditure group. We have set at zero the level corresponding to negative expenditure.

Needless to say, these obvious mistakes are numerically insignificant, and do not change the main results.

In the ENGH 96/97 and the ENGH 04/05, there is information about households with imputed income and expenditure, ${ }^{13}$ but not in the EGH 85/86, as a consequence. we will assume that the imputation method used by the INDEC is valid and similar across surveys.

The EGH 85/86 was conducted between July 1985 and June 1986. The base indicates the quarter in which each household has been surveyed. Based on this information, we have paired the data with the corresponding CPI level (and its categories) corresponding to the average for each quarter.

ENGH 96/97 took place between February 1996 and March 1997, but numbers have been taken nominal values relative to the average CPI during the period, as there is no information as to the specific quarter in which the survey was conducted. Fortunately, this is a very low inflation period, and therefore, whatever mistake arises from this must necessarily be minimal. ${ }^{14}$

ENGH 04/05 took place between October 2004 and December 2005. The base indicates the quarter in which each household was surveyed, and therefore, the procedure followed is similar that used for EGH 85/86.

\section{Appendix B: Additional tables}

See Tables 7, 8, 9, and 10 .

\footnotetext{
12 These numbers correspond only to households from Buenos Aires and its Metropolitan Area, and to the city of Buenos Aires in the last sample.

$1326.8 \%$ of incomes in Buenos Aires and its Metropolitan Area are imputed in ENGH 96/97, 28.1\% of incomes and $26.4 \%$ of expenditures in Buenos Aires are totally or partially imputed in ENGH 04/05.

14 Cumulative inflation between February 1996 and March 1997 is about 0.4\%; instead, cumulative inflation between July 1985 and June 1986 arises to $41.3 \%$.
} 


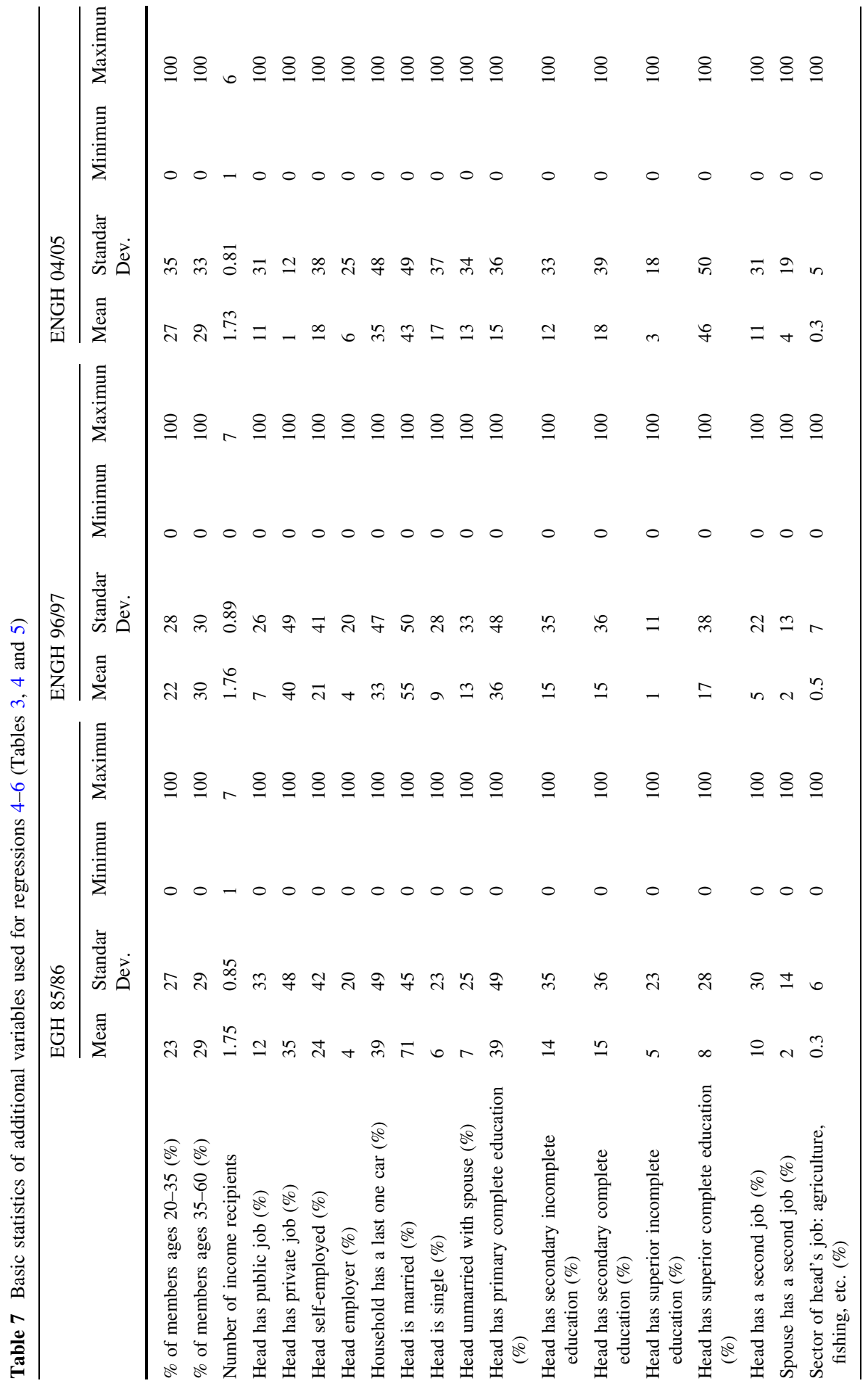




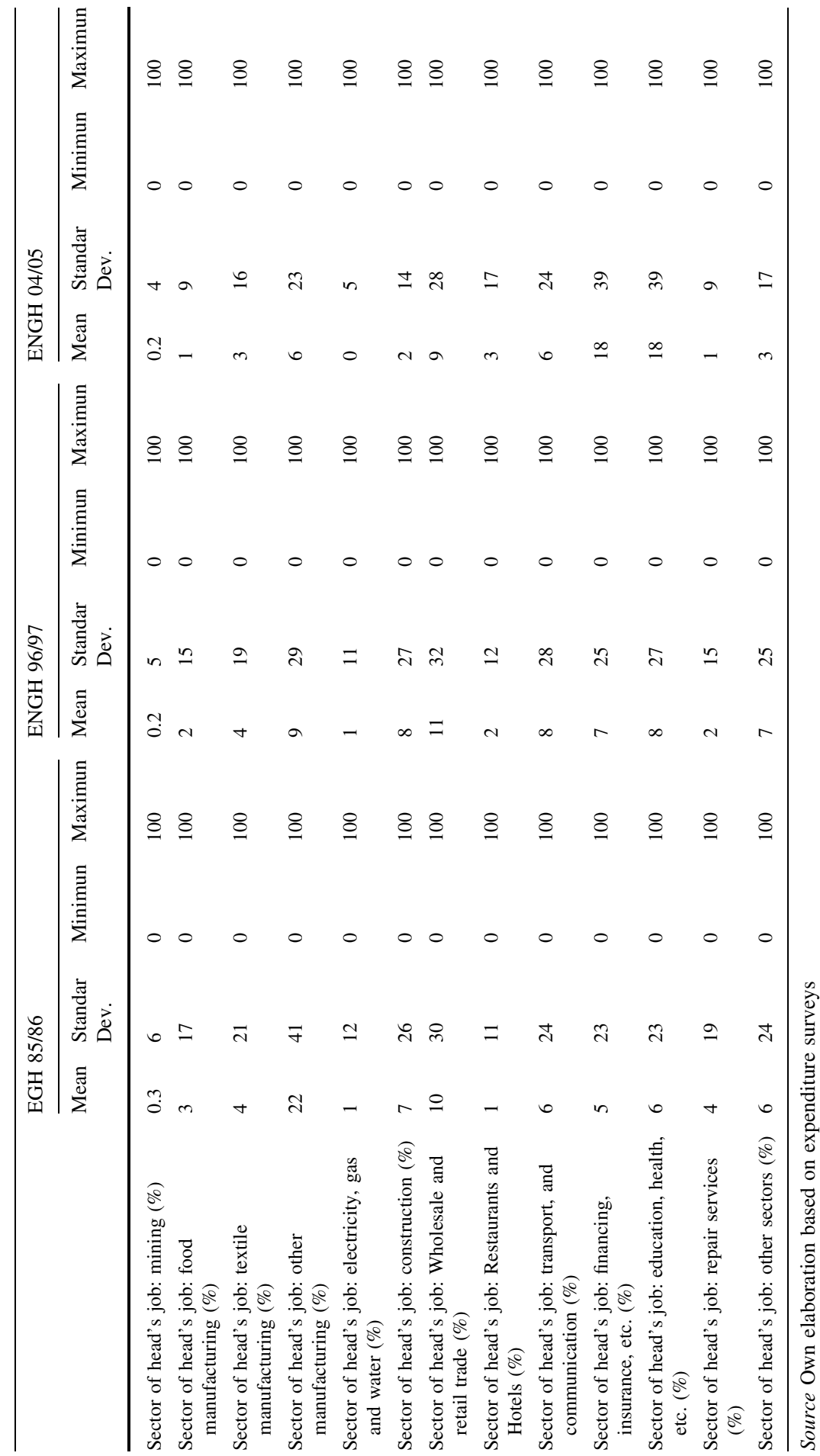




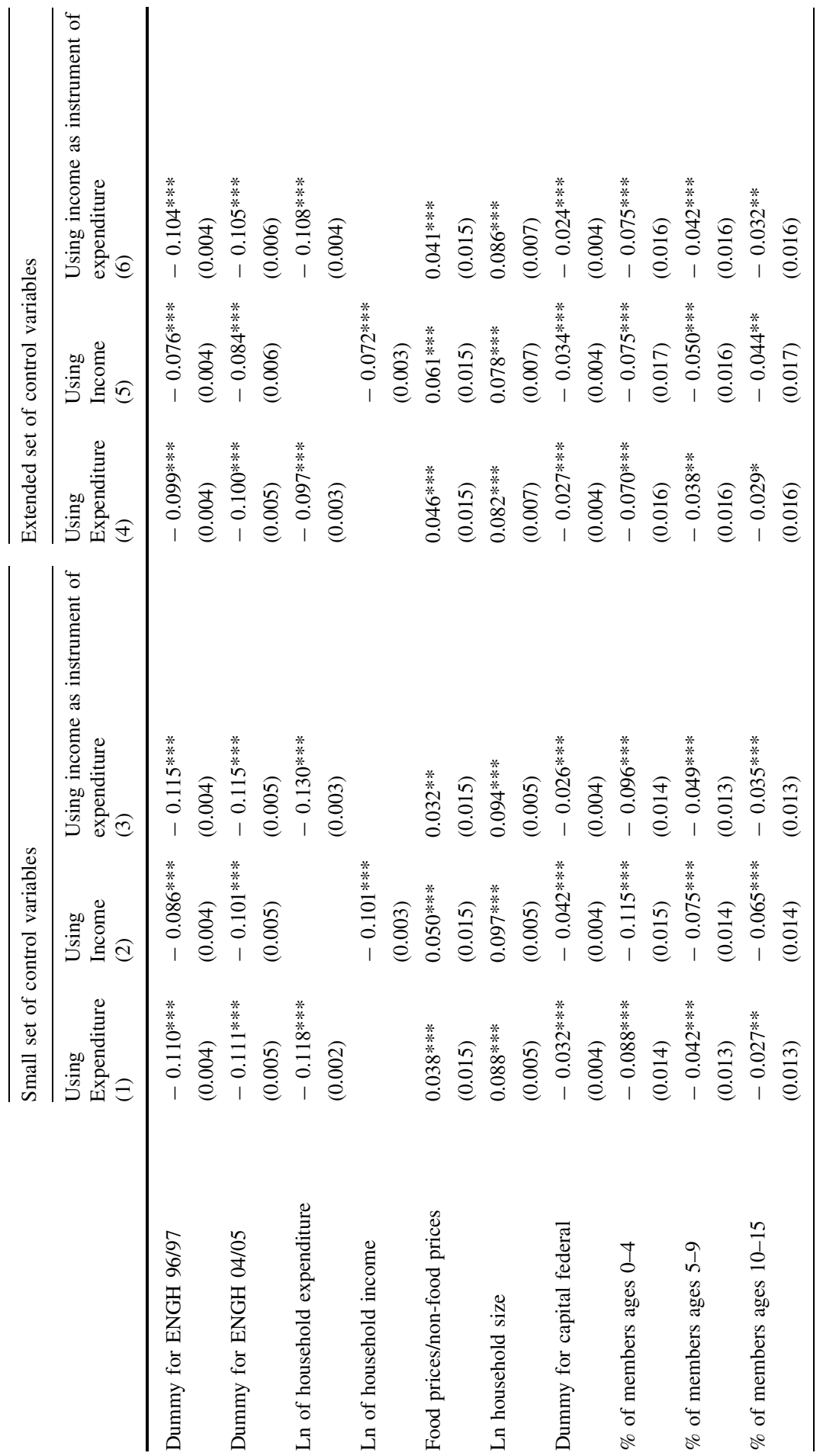




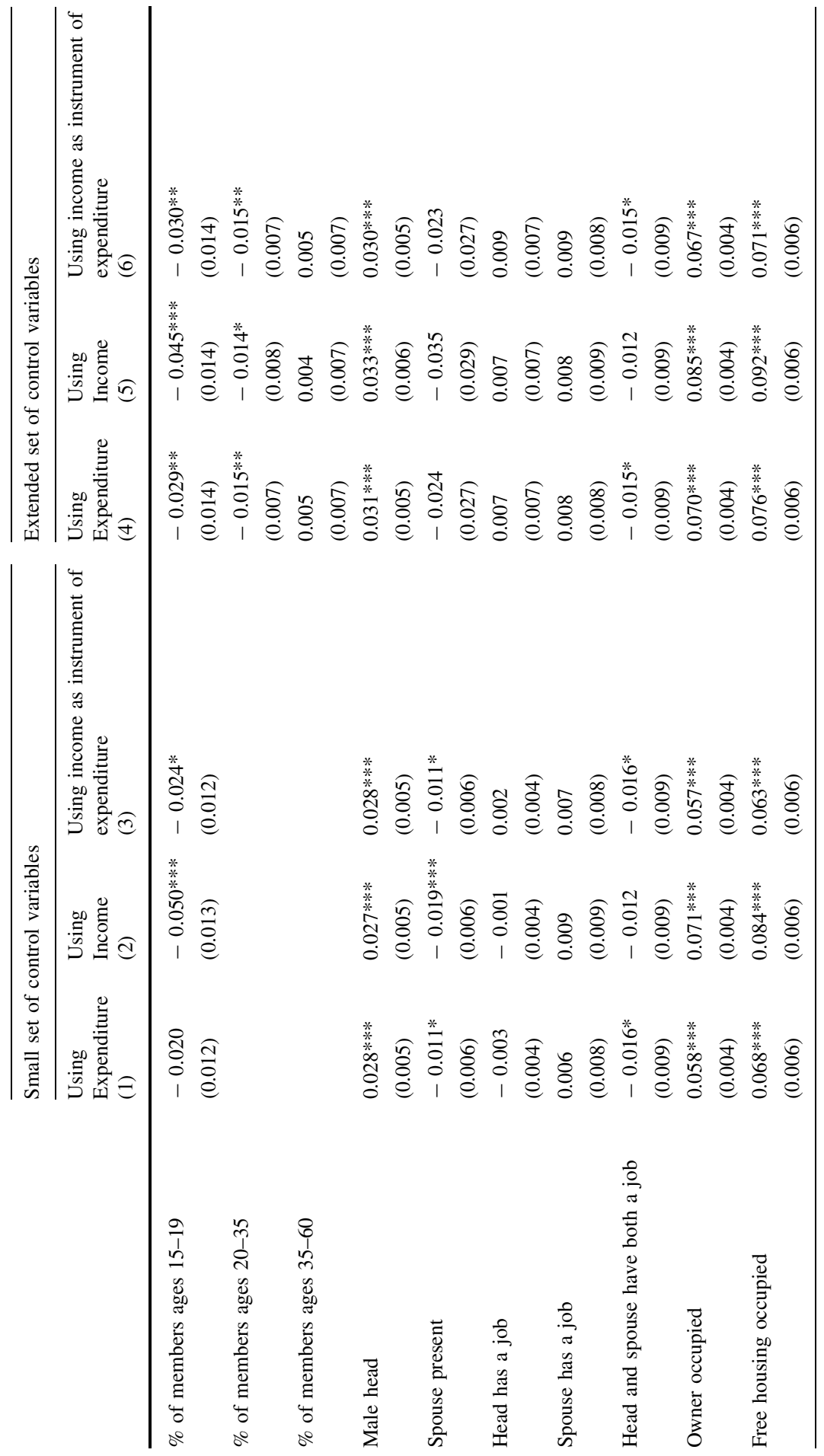




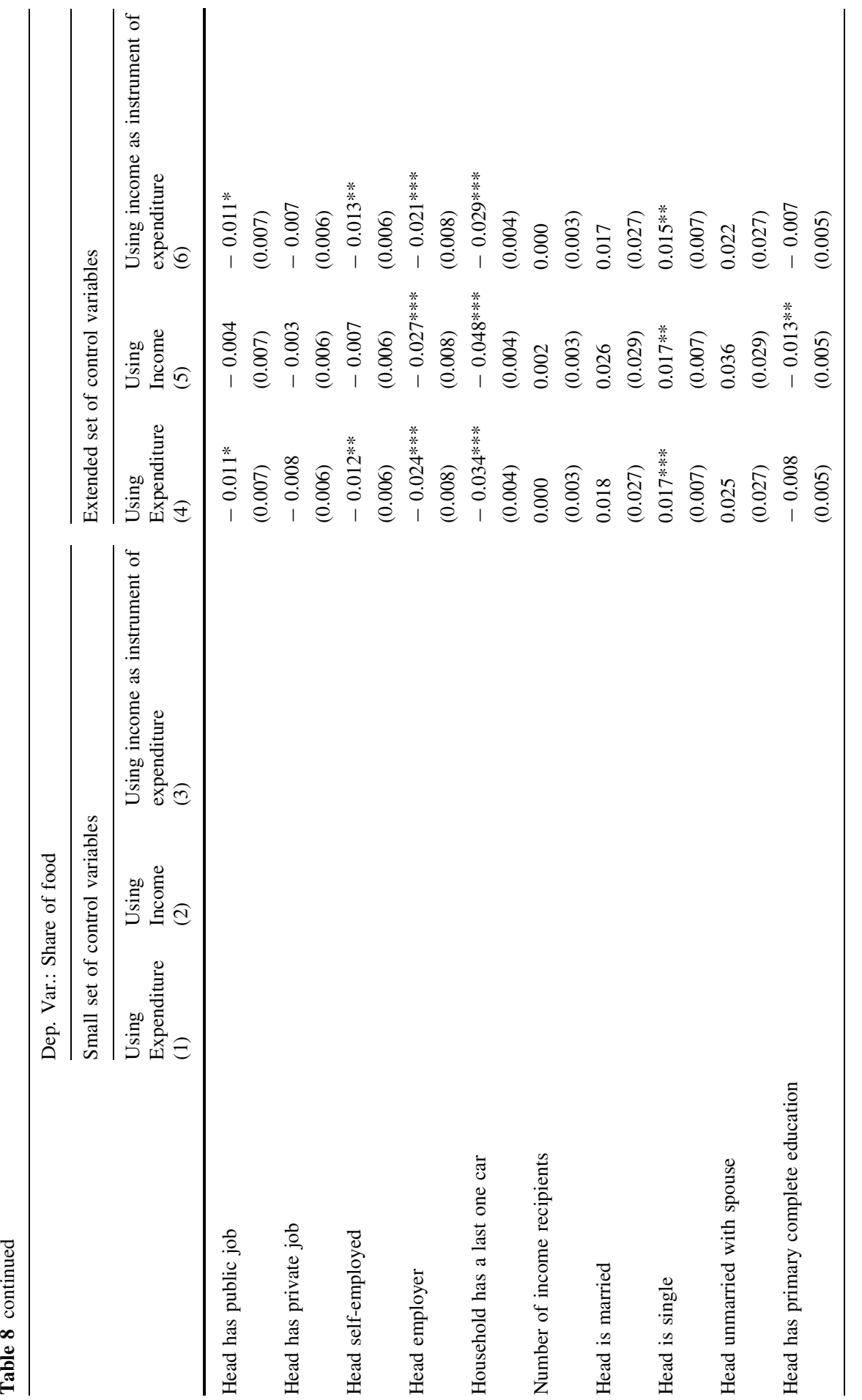




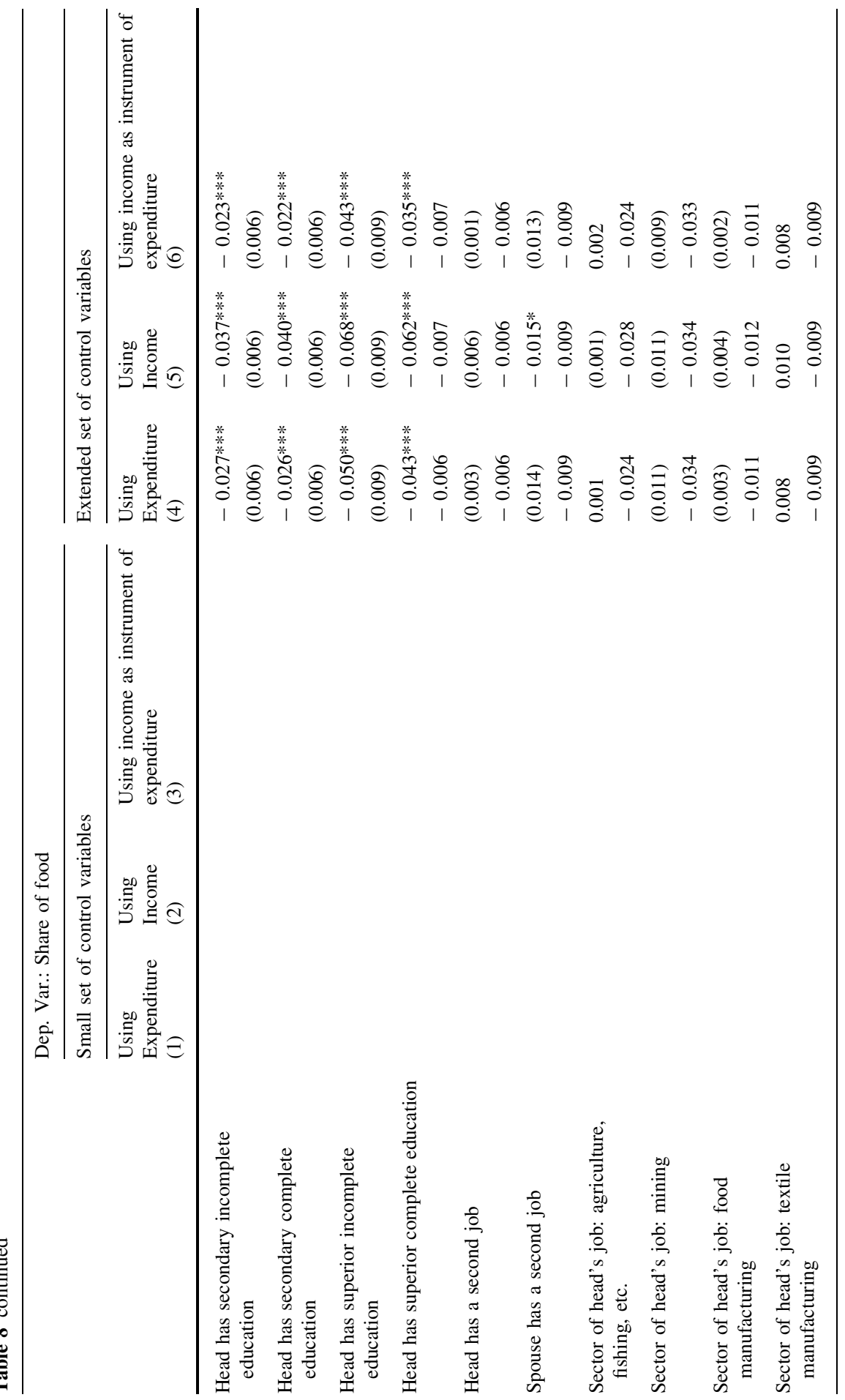




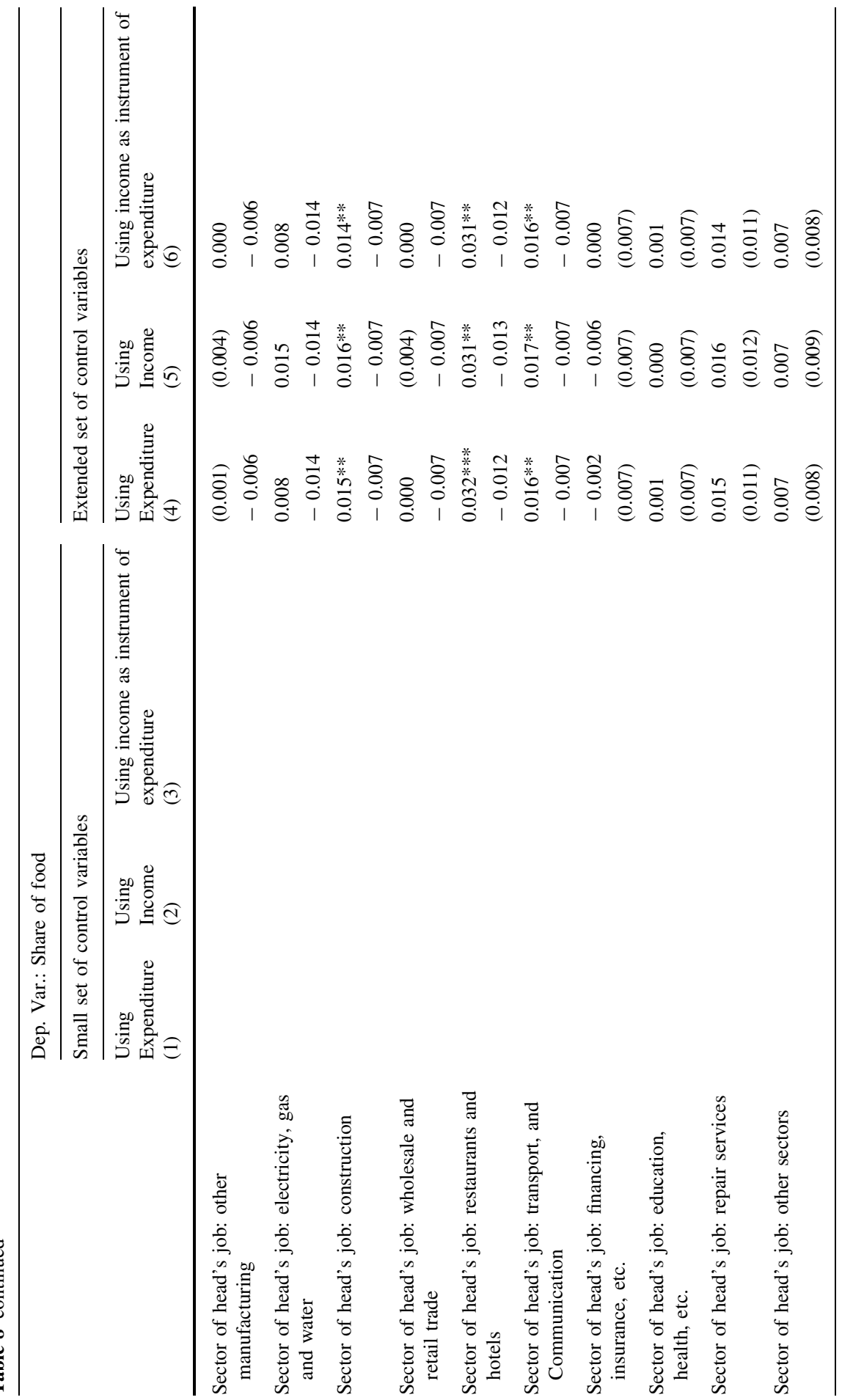




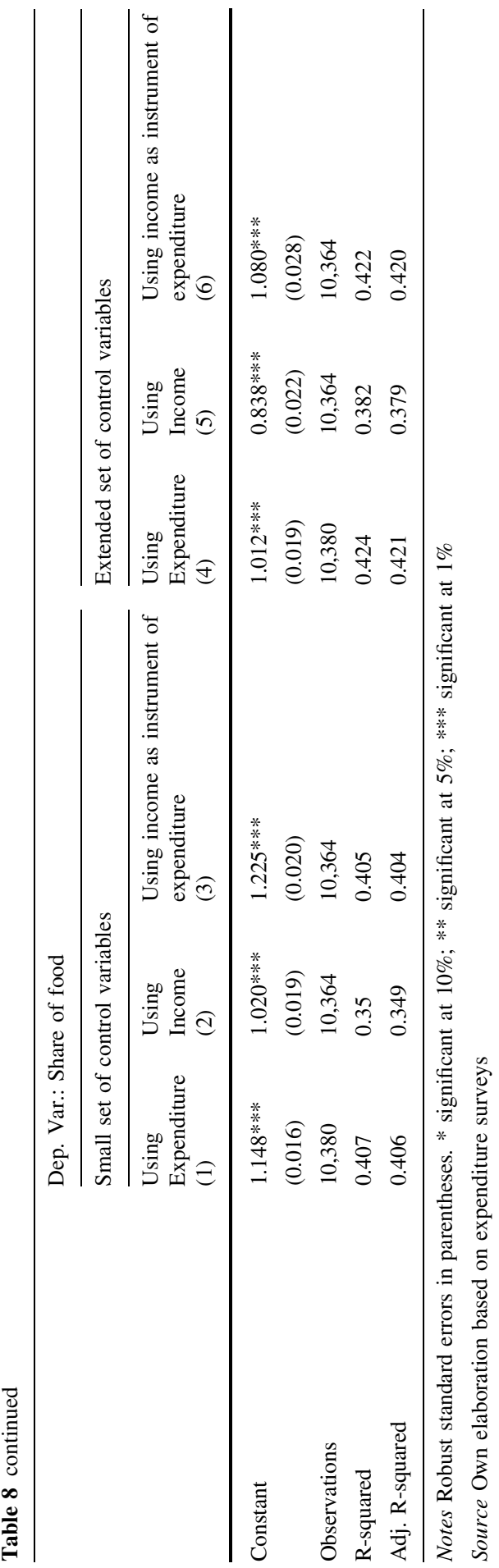




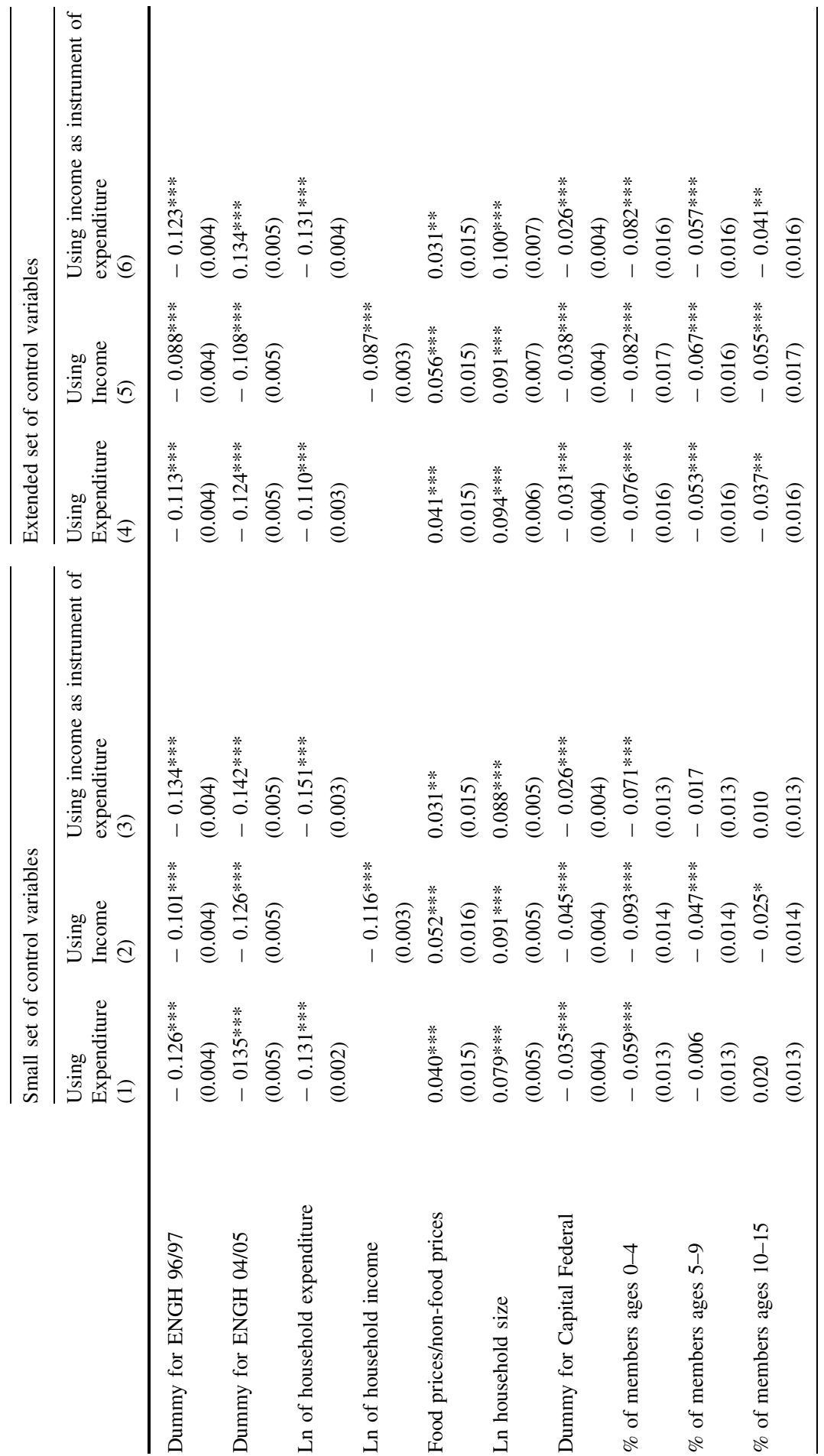




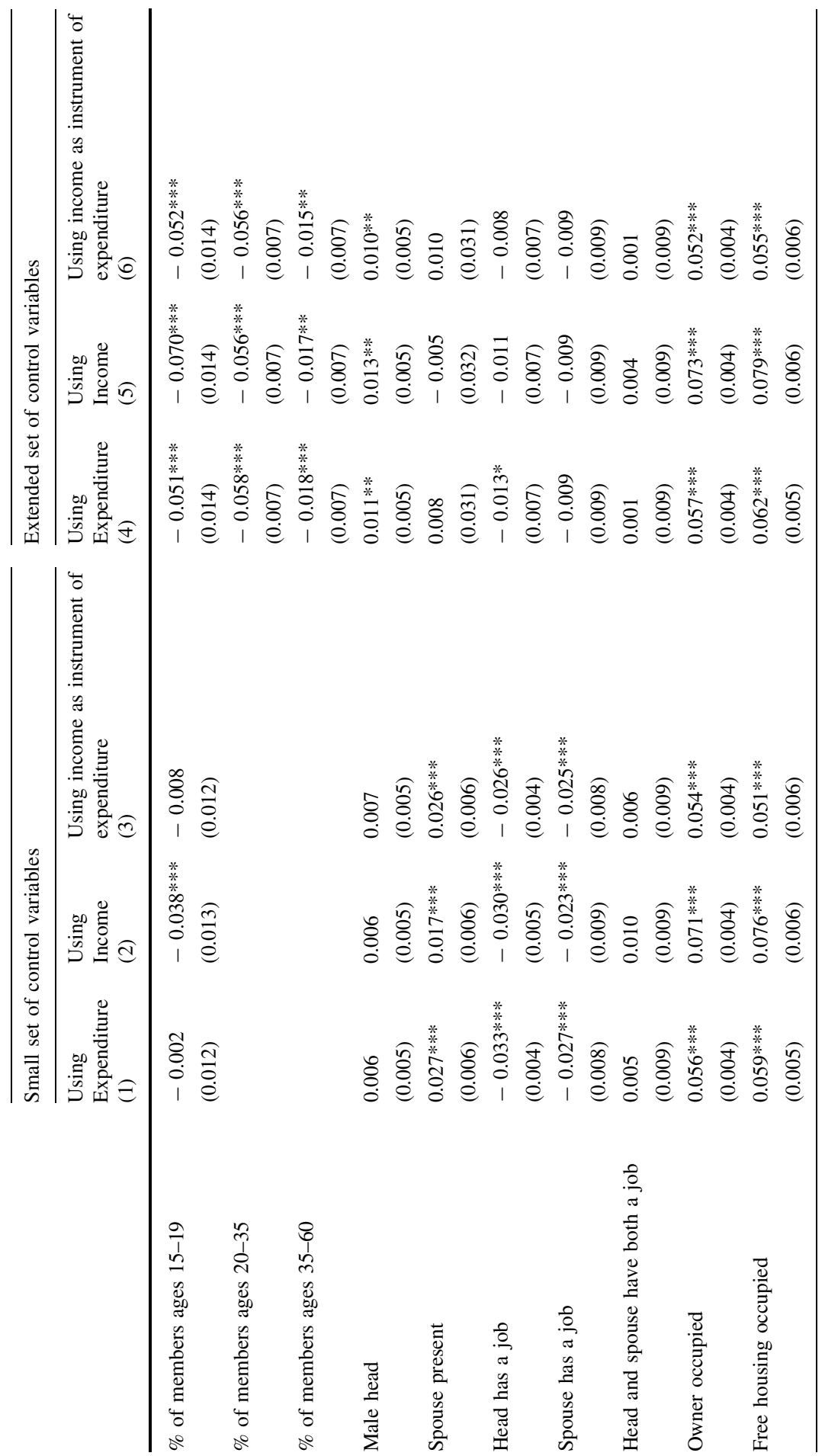




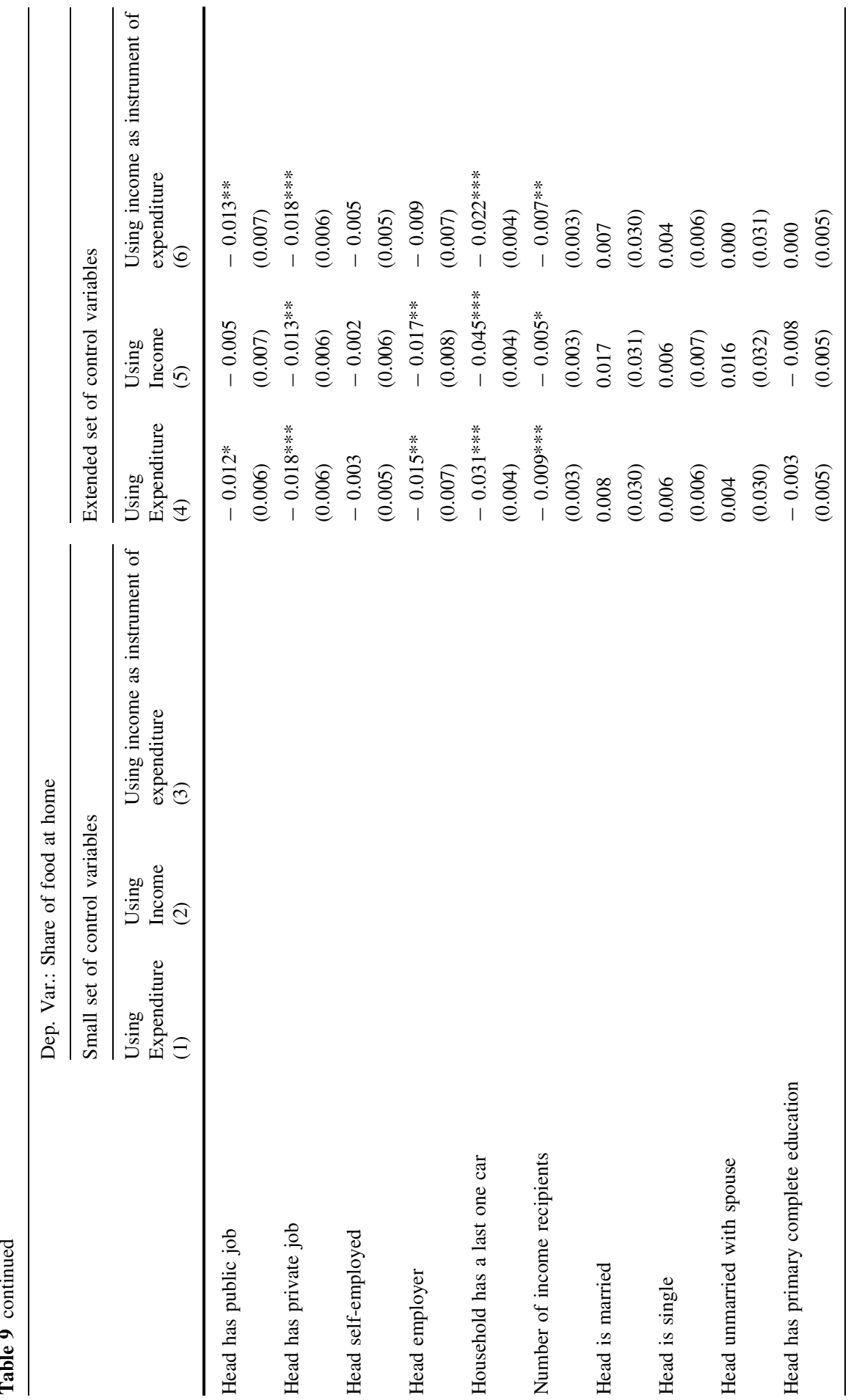




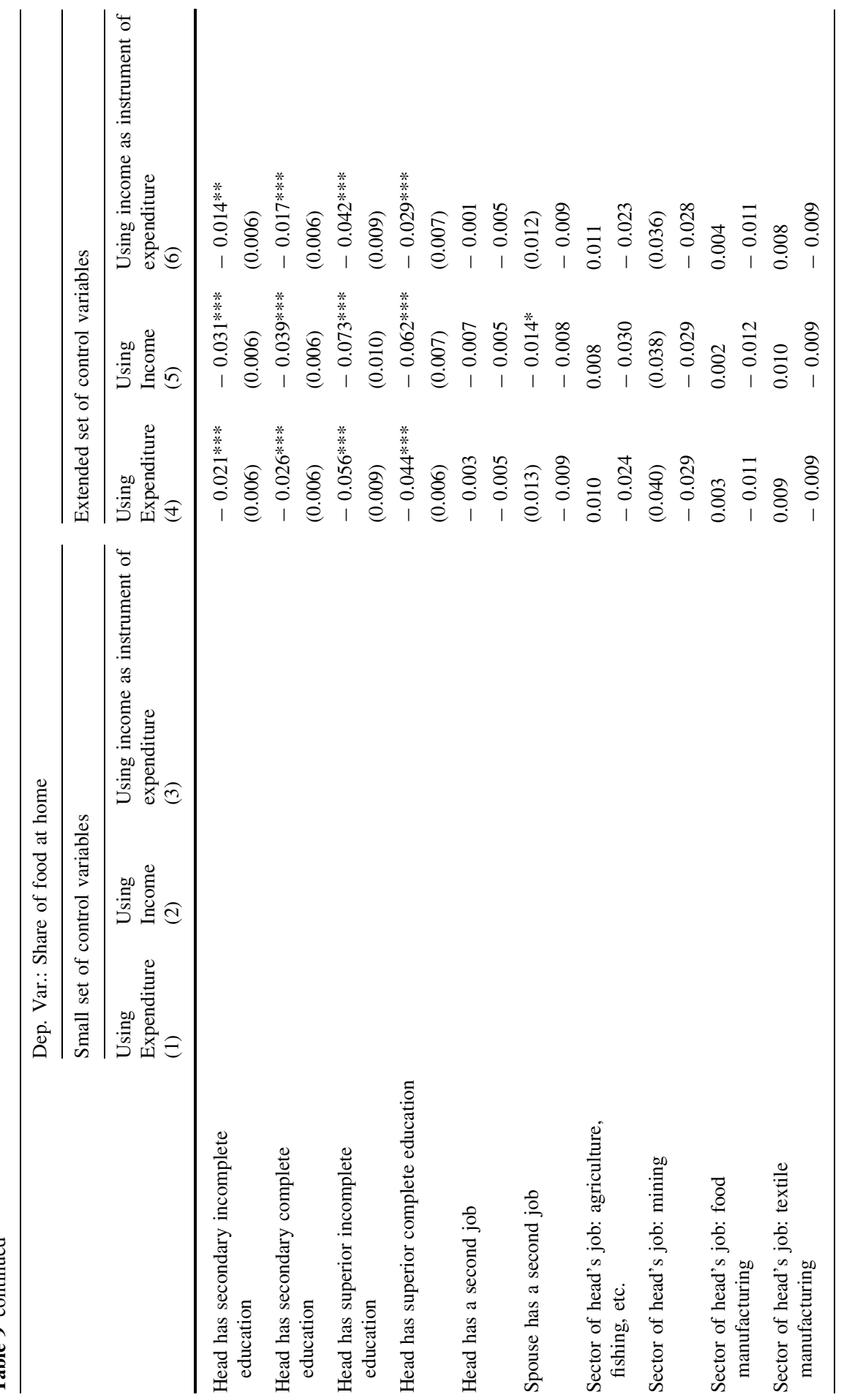




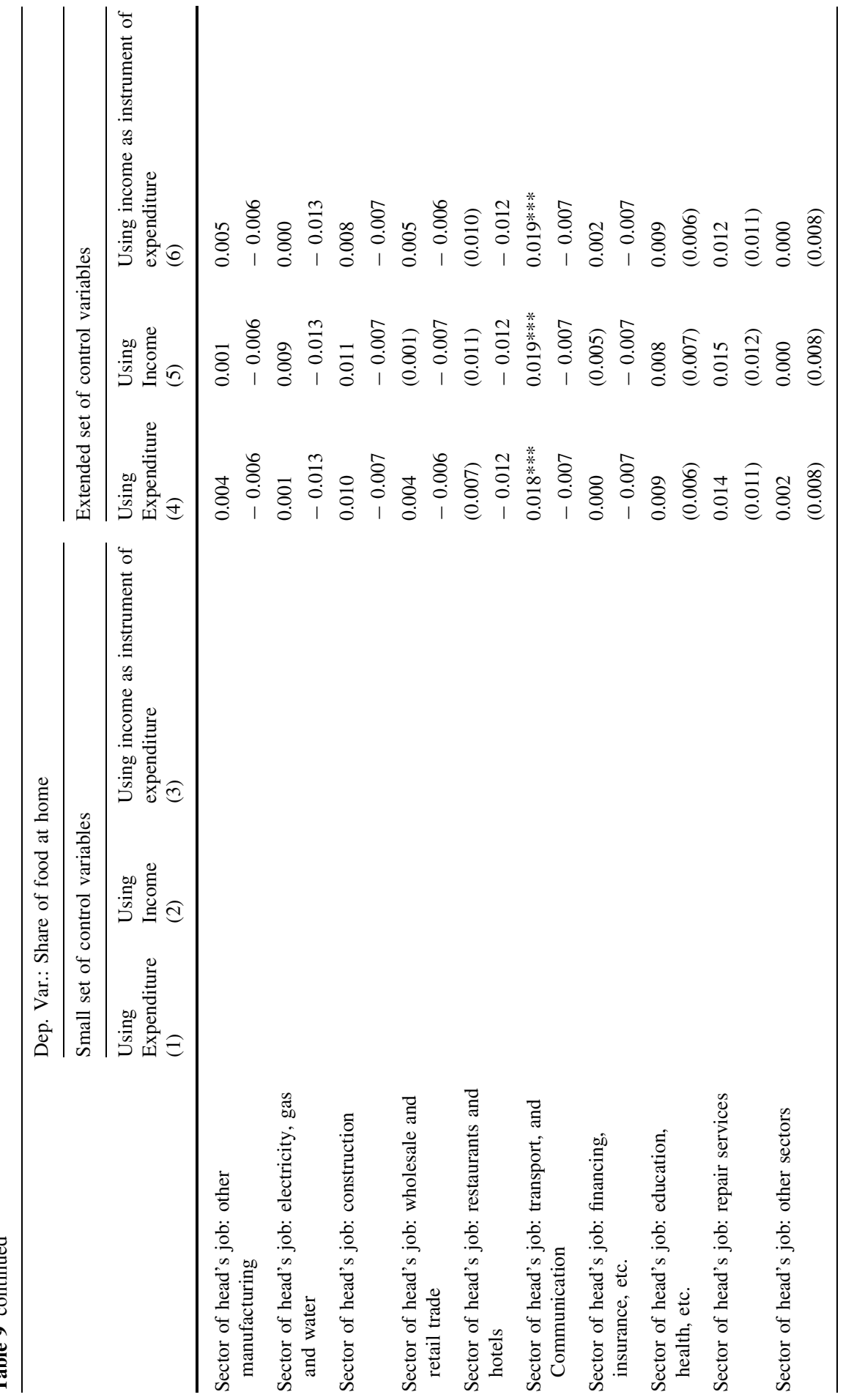




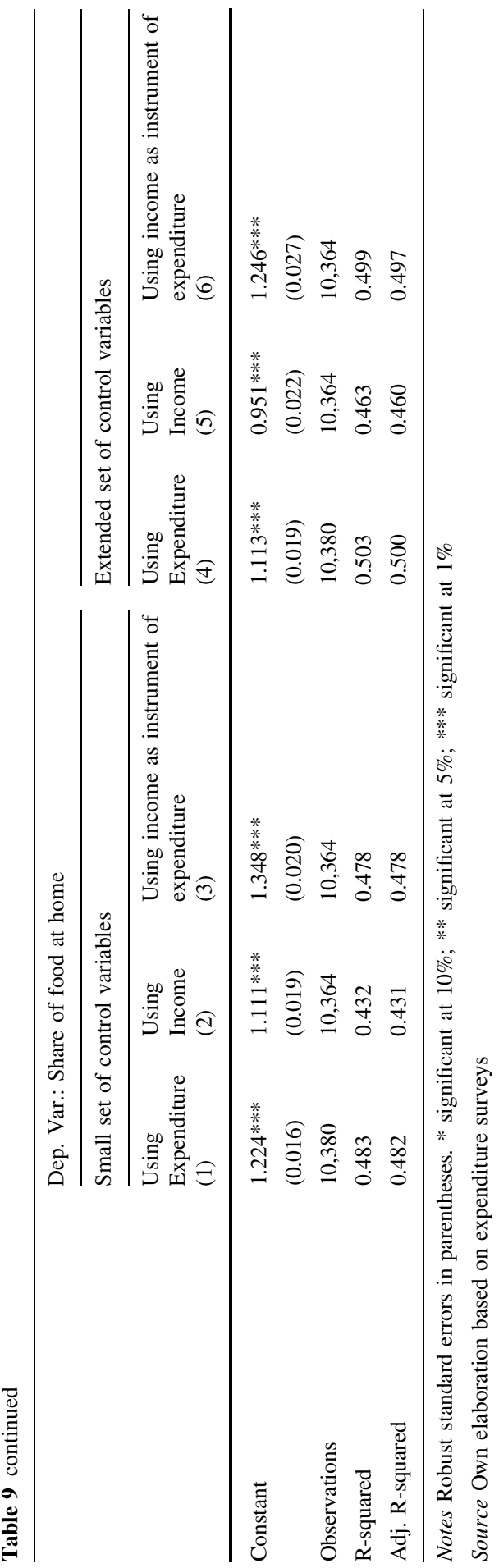




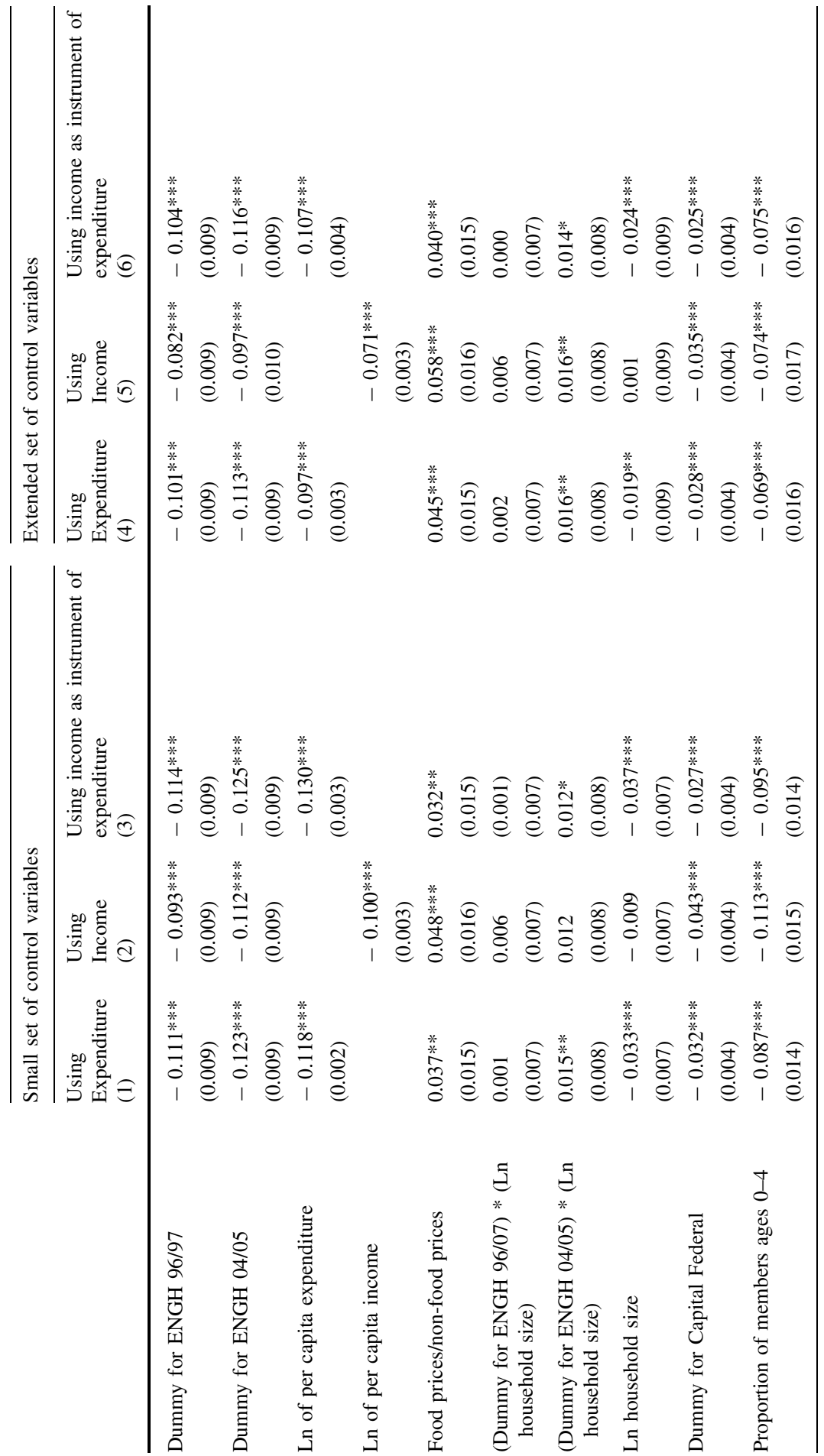




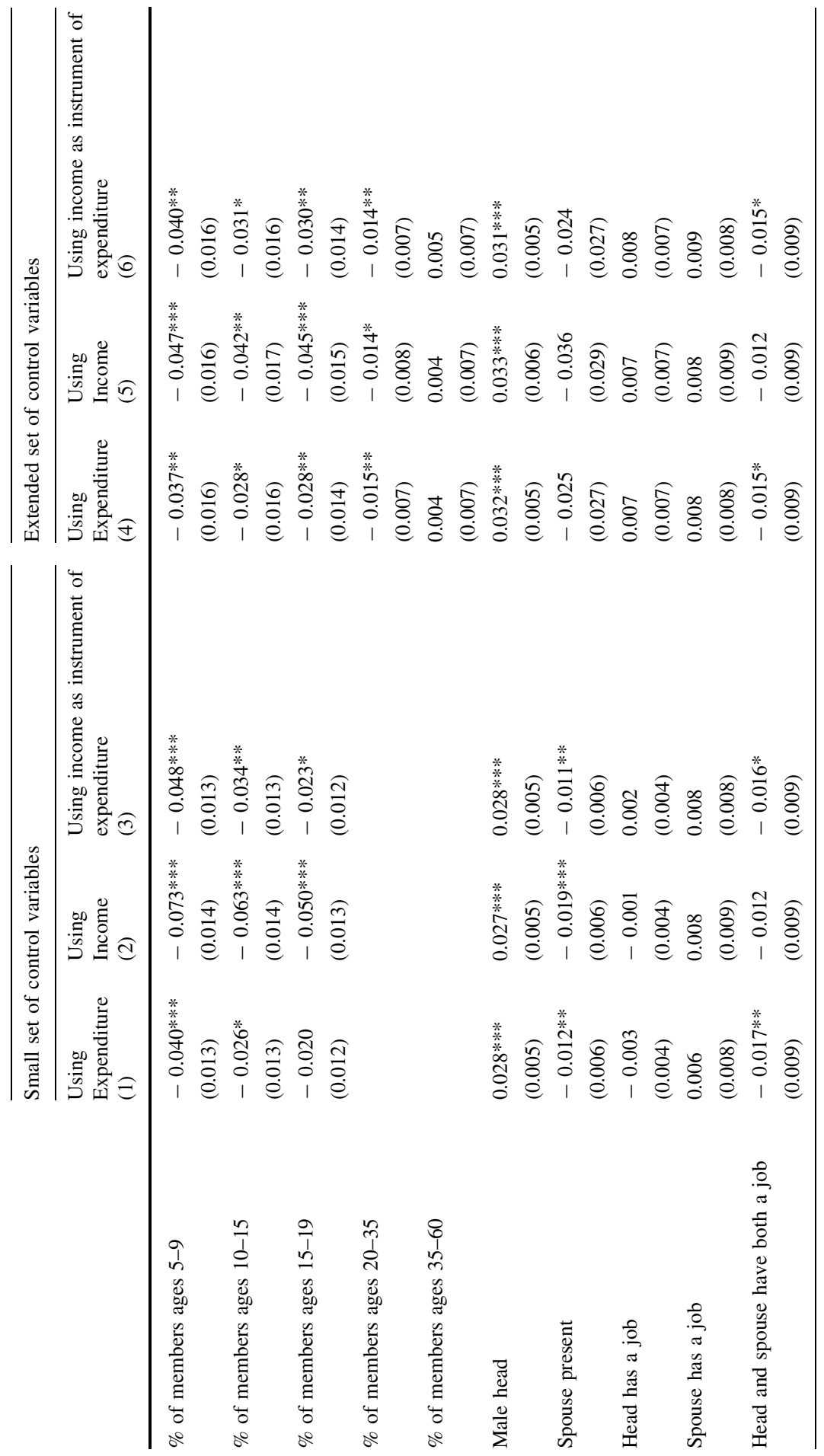




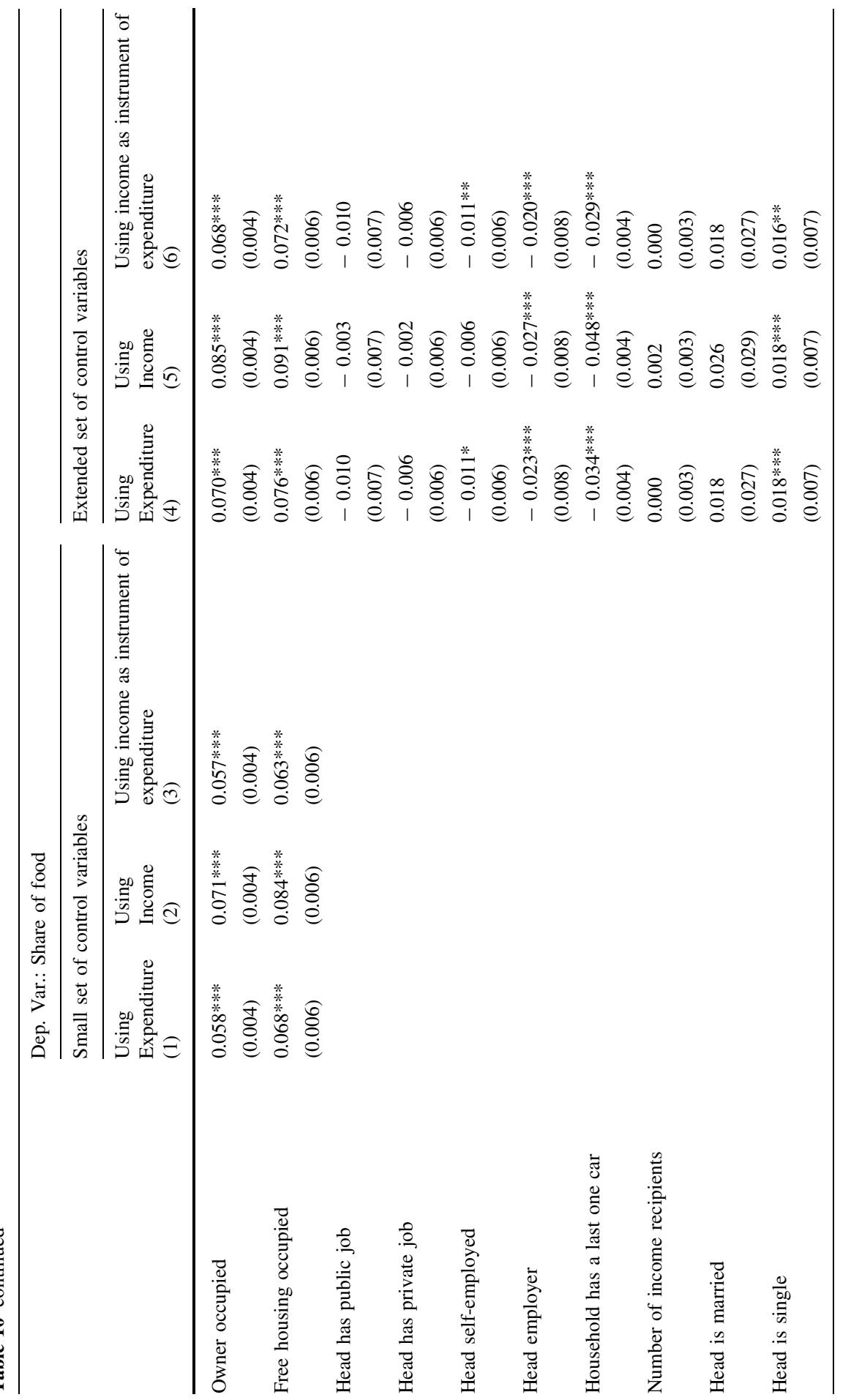




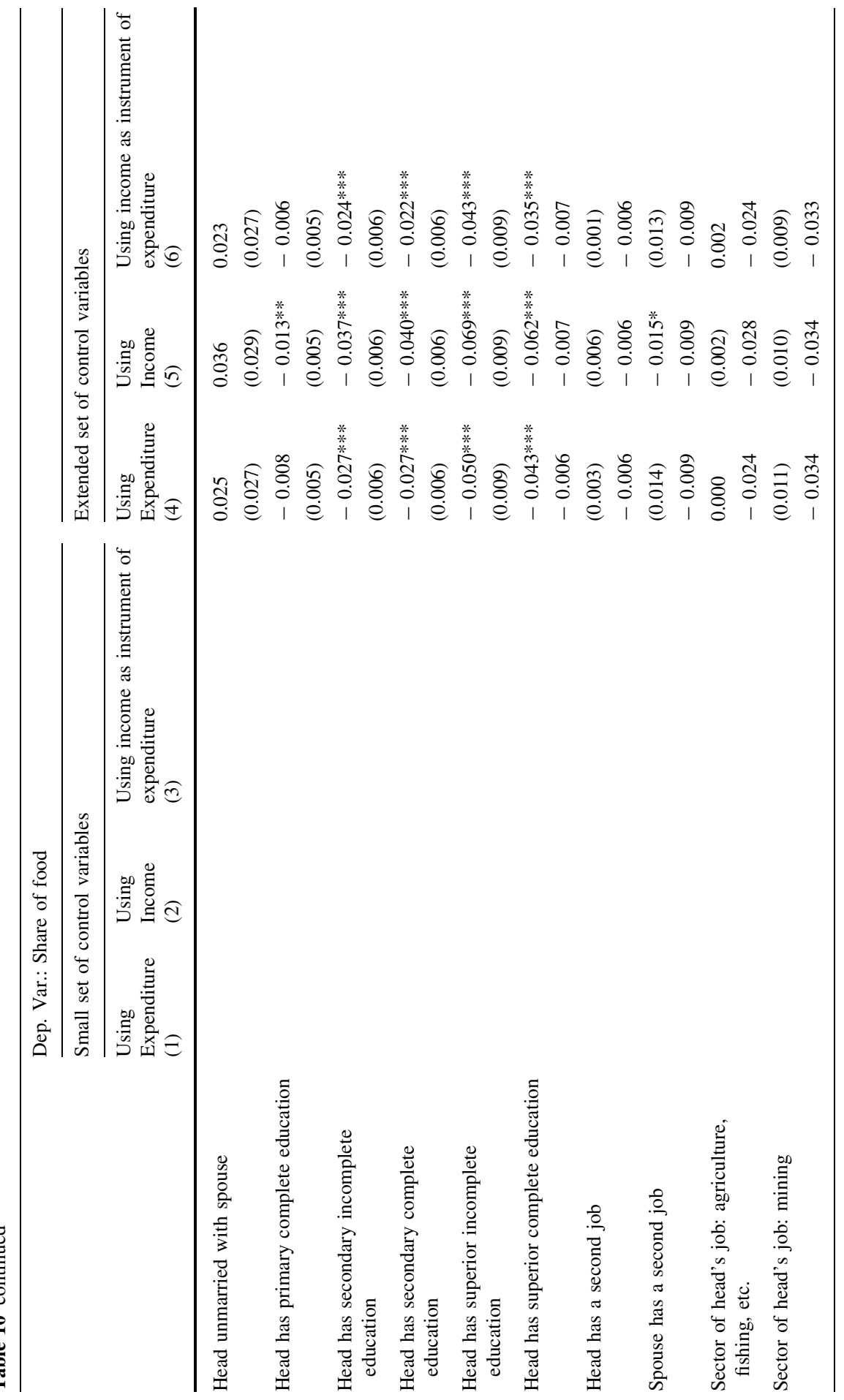




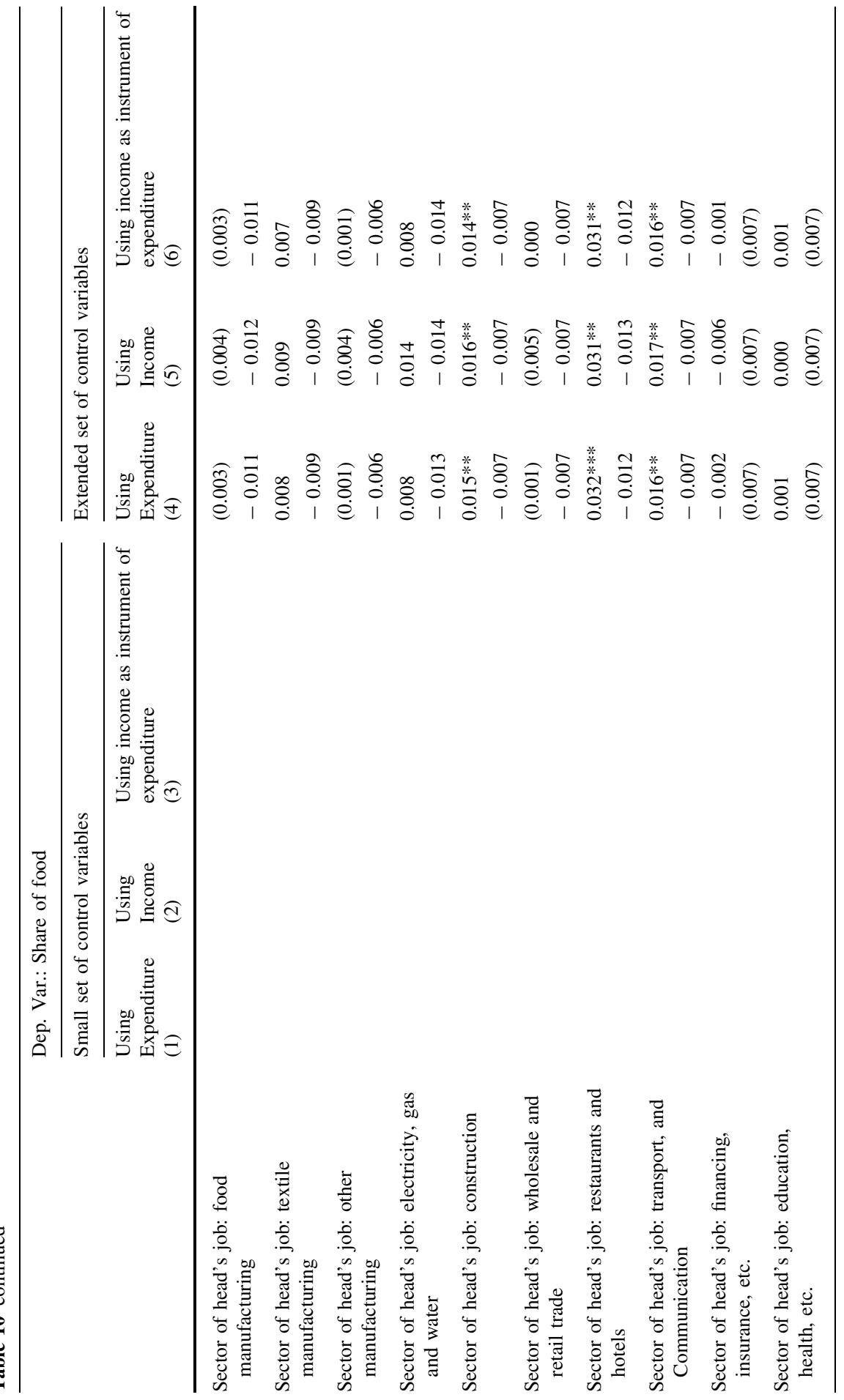




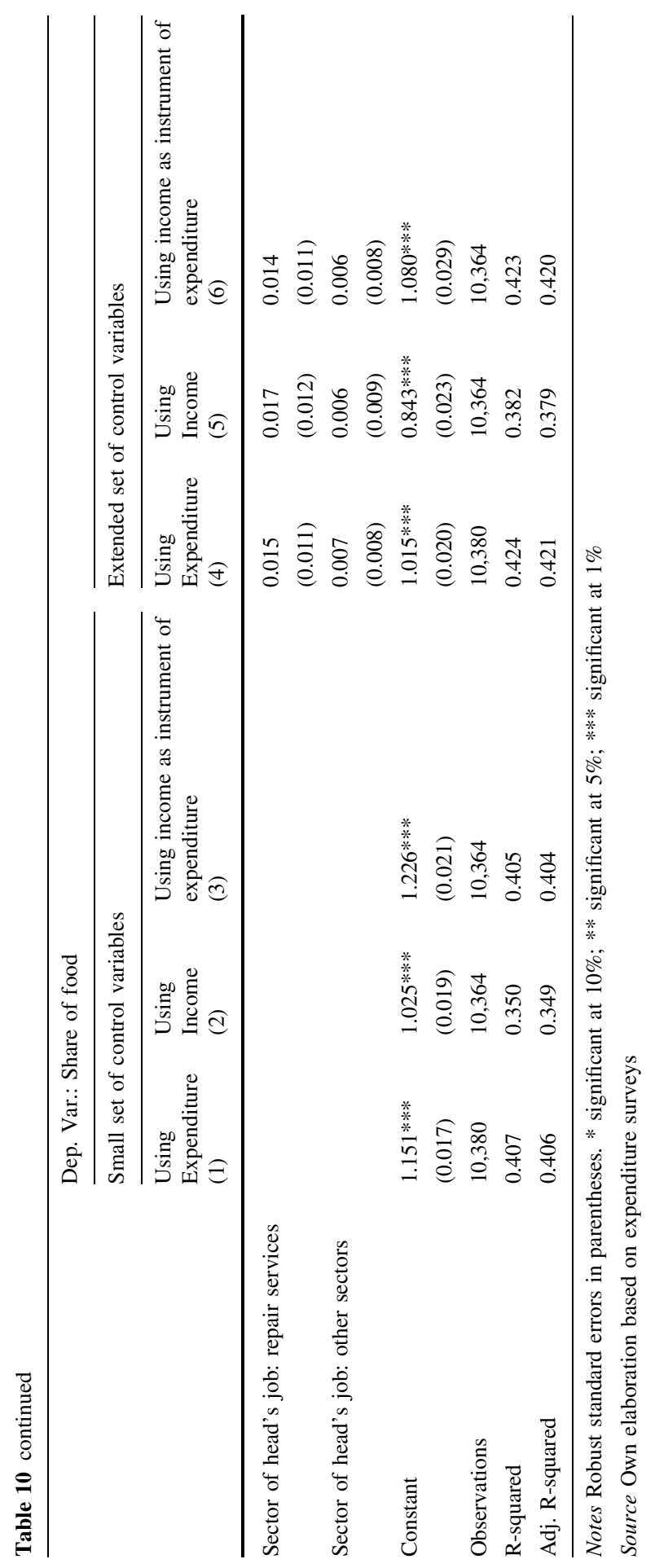




\section{References}

Altimir O, Beccaria L (2001) El persistente deterioro de la distribución del ingreso en la Argentina. Desarrollo Económico 40(160):589-618

Altimir O, Beccaria L, Gonzalez Rozada M (2002) La distribución del ingreso en Argentina, 1974-2000. Revista Cepal 78:55-86

Carvalho Filho I, Chamon M (2012) The myth of post-reform income stagnation: evidence from Brazil and Mexico. J Dev Econ 97(2):368-386

Costa D (2001) Estimating Real Income in the United States from 1888 to 1994: correcting CPI Bias Using Engel Curves. J Political Econ 109(6):1288-1310

Cruces G, Gasparini L (2009) Desigualdad en Argentina. Una revisión de la evidencia empírica. Desarrollo Económico 48(192):395-437

Damill M, Frenkel R (1992) Malos tiempos. La economía argentina en la década de los ochenta. In Damill M, Frenkel R (Eds.) Argentina: evolución macroeconómica, financiación externa y cambio político en la década de los ochenta. Fundación Cedeal, Madrid

Damill M, Frenkel R (2003) Argentina: Macroeconomic performance and crisis. Initiative for policy dialogue, Working paper, June 2003

Damill M, Frenkel R, Mauricio R (2002) Argentina: A decade of currency board. An analysis of growth, employment and income distribution, International Labour Office Geneva, Employment Paper $\mathrm{N}^{\circ} 42$

Diaz Alejandro C (1970) Ensayos sobre historia económica argentina. Amorrortu, Buenos Aires

Diewert E, Greenlees J, Hulten C (2010) Price index concepts and measurement. University of Chicago Press, Chicago

Gabrielli MF, Rouillet MJ (2003) Growing unhappy?: An empirical approach. BCRA

Gasparini L (2005) Argentina's distributional failure: the role of integration and public policies. In: Márquez G (ed) Debate sobre el Impacto de la Globalización en los Mercados de Trabajo de América Latina. Inter-American Development Bank, Washington

Gerchunoff P, Llach L (2003a) Ved en Trono a la Noble Igualdad. Crecimiento, equidad y política económica en la Argentina. PENT, Buenos Aires, pp 1800-2003

Gerchunoff P, Llach L (2003b) El Ciclo de la Ilusión y el Desencanto: Un Siglo de Políticas Económicas Argentinas. Ariel, Buenos Aires

Gerchunoff P, Llach L (2004) Entre la equidad y el crecimiento. Siglo Veintiuno, Buenos Aires

Hamilton B (2001) Using Engel's Law to Estimate CPI Bias. American Economic Review 91(3):619-630

Lindenboim J, Graña J, Kennedy D (2005) Distribución funcional del ingreso en Argentina. Ayer y hoy. Cuaderno de Trabajo N. 4, CEPED, Universidad de Buenos Aires

Trebon L (2008) Are Engel Curve estimates of CPI bias biased?. NBER, Working Paper 13870

Yatchew A (1997) An elementary estimator of the partial linear model. Econ Lett 57(2):135-143 